\title{
ATLANTIC GEOSCIENCE SOCIETY
}

\author{
ABSTRACTS
}

1991 MINI-SYMPOSIUM

"ENVIRONMENTAL GEOLOGY"

1991 COLLOQUIUM

"CURRENT RESEARCH IN THE ATLANTIC PROVINCES"

\section{WOLFVILLE, NOVA SCOTIA}

The 1991 Mini-Symposium and Colloquium of the Atlantic Geoscience Society were held at the Wandlyn Motor Inn, Amherst, Nova Scotia on February 8-9, 1991. On behalf of the Society we thank David Mossman of Mount Allison University and all others involved in the organization of this excellent meeting.

In the following pages we publish the abstracts of talks and poster sessions given at the MiniSymposium and Colloquium. 


\title{
Specification of earth resources satellites and their utility for environmental geology
}

\author{
M.S. Akhavi \\ Remote Sensing Program, College of Geographic Sciences, P.O. Box 10, Lawrencetown, Nova Scotia BOS 1M0, Canada
}

Earth resources satellites have been used for about two decades to assist in geologic exploration and environmental monitoring world wide. Synoptic and repetitive coverage, multispectral sensitivity, and high resolution are among the advantages of spaceborne imagery.

A second generation satellite, the Landsat Thematic Mapper (TM), covers a broad portion of the electronmagnetic spectrum, and consists of seven discrete bands covering visible, reflected and thermal infrared regions. Six reflective TM bands have a resolution of $30 \mathrm{~m}^{2}$ and are utilized for coastal water mapping, geobotanical investigations, and biomass control, as well as other applications. TM band 6 has a resolution of $120 \mathrm{~m}^{2}$; it is useful in vegetation stress analysis, soil moisture discrimination, and thermal mapping.

The emergence of SPOT, a French satellite, initiated a new era in space remote sensing. The multispectral "push-broom" scanner consists of three bands with a resolution of $20 \mathrm{~m}^{2}$, while a panchromatic band provides a high resolution of $10 \mathrm{~m}^{2}$ from space. Stereoscopic imaging and successive day "revisit" capabilities of this satellite are pertinent to dynamic or catastrophic geology.

Nineteen hundred ninety is the decade of spaceborne radar because five synthetic aperture radar systems would operate from space. The prospect of repetitive coverage from orbital radar systems holds considerable potential for geologic exploration and environmental monitoring.

\section{Late Precambrian-Cambrian magmatic evolution of southern New Brunswick and southeastern Cape Breton Island, Nova Scotia}

\author{
S.M. Barr, C.E. White \\ Department of Geology, Acadia University, Wolfville, Nova Scotia BOP 1X0, Canada \\ M.L. Bevier \\ Geological Survey of Canada, 601 Booth Street, Ottawa, Ontario K1A OE8, Canada \\ and \\ E. Hegner \\ Universitat Tubingen, Tubingen, Germany
}

New U.Pb (zircon) dates from igneous units combined with geological mapping and petrochemical studies are clarifying the Precambrian and Early Palaeozoic magmatic evolution of the Mira and Bras d'Or terranes of Cape Breton Island and the corresponding Caledonia and Brookville terranes of southern New Brunswick. The Mira and Caledonia terranes are characterized by abundant volcanic rocks formed in a continental volcanic arc setting and range in age from ca. $675 \mathrm{Ma}$ to $600 \mathrm{Ma}$. They are associated with calc-alkalic dioritic to granitic plutons dated at ca. 615 to $625 \mathrm{Ma}$. Younger (ca. $550 \mathrm{Ma}$ ) dominantly bimodal volcanism and related high-level granitic and dioritic/gabbroic plutons formed in a post-subduction extensional setting. Both volcanic and plutonic units in the Mira Terrane have positive initial $\varepsilon N d$ values from +0.8 to +5.0 that indicate juvenile sources. This juvenile crust is also present under southem New Brunswick, although zircon inheritance indicates that old (Early Proterozoic and Archaean) continental crust is also present. In contrast, the Bras d'Or and Brookville terranes lack abundant volcanic rocks and are characterized by Late Precambrian gneisses and sedimentary successions, intruded by calc-alkalic dioritic to granitic plutons ranging in age from ca. 565 to $540 \mathrm{Ma}$ and formed in a continental margin subduction zone. Late posttectonic granitic plutonism occurred at ca. $500 \mathrm{Ma}$ (Early Ordovician). Initial $\varepsilon N d$ values are generally negative and, combined with zircon inheritance, indicate involvement of early to midProterozoic continental crust.

Textural development in experimental shear zones using analogue materials

\author{
C.J. Beaumont-Smith and P.F. Williams \\ Centre for Deformation Studies in the Earth Sciences, Department of Geology, University of New Brunswick, \\ Fredericton, New Brunswick E3B 5A3, Canada
}

The use of soft organic materials as rock analogues has become popular in the study of rock deformation. Their low strength and relatively low melting temperature allow ductile deformation experiments to be conducted at elevated strain rates and high homologous temperatures thus permitting in situ obser- vations to be made of fabric development in the resulting shear zones.

The experimental procedure used here is to deform paradichlorobenzene $\left(\mathrm{C}_{6} \mathrm{H}_{4} \mathrm{Cl}_{2}\right)$ at room temperature in a shear zone situated between two microscope slides. The samples are de- 
formed in a Urai press that is attached to a microscope stage. The deformation is viewed microscopically and is recorded either by still or time lapse photography. The deformation takes place in a shear zone approximately $3 \mathrm{~mm}$ wide and at a strain rate of approximately $10^{-5} \mathrm{~s}^{-1}$. At room temperature paradichlorobenzene (PDCB) is at homologous temperature in excess of 0.9 .

The original PDCB igneous texture of coarse acicular grains evolves throughout the deformation until a steady-state dynamically recrystallized $\mathrm{S}-\mathrm{C}$ fabric is attained. The modification of the original texture starts with kinkband formation and is dominated by kink band and grain boundary migration processes. Strongly distorted grains are preferentially consumed by the migration of adjacent grain boundaries of subgrain-free grains into grains with subgrains. Although lacking crystallographic orientation information, these observations appear to demonstrate the evolution of a steady-state foliation. Once an apparent steady-state grain size has been achieved, the surviving neoblasts show little subgrain development. The sample continues to accumulate strain through the progressive rotation of the foliation towards the shear plane with much of the flattening accommodated by the movement of grains along grain boundaries. The strain is considerably more heterogeneous than the resulting microstructure.

\title{
Seismic interpretation, potential overthrust geology and mineral deposits in the Kennetcook Basin, Nova Scotia \\ R.C. Boehner \\ Nova Scotia Department of Mines and Energy, P.O. Box 1087, Halifax, Nova Scotia B3J 2X1, Canada
}

The occurrence of thrust/reverse faults with a range of magnitudes and associations has been reported at various localities in Carboniferous basins, including the Kennetcook Basin adjacent to the Cobequid-Chedabucto Fault System (CCFS) and the Triassic Rift. Although the inferred relationship between tectonics and metallogenesis in the basins is controversial, it would be important both for the genesis of mineral deposits and their subsequent disruption. The structural geology of the Kennetcook Basin is complex and appears to be compatible with restraining-convergence tectonics on subsidiary faults related to dextral east-west strike slip motion on the CCFS. Superposition of the Triassic Rift in a later extensional environment has further complicated the interpretation of the structural history.

Evidence for overthrusting has been previously restricted to small scale thrust fault occurrences (tens of metres) reported near the western extremity of the basin. Reflection seismic survey lines across the basin near Kennetcook and Noel by Soquip et al., together with deep and shallow exploration drillholes, permit the definition of the gross basin configuration. Interpretation of large scale features of the seismic lines indicates that the southeast border of the basin is a major high-angle fault ( $2300 \mathrm{~m}$ dip-slip) and that the north border appears to be a southward overthrust of deformed Horton Group and basal Windsor Group (together with numerous mineral occurrences). The concept that post-mineralization overthrusting along the northwest border of the basin (Walton Belt) may have concealed significant $\mathrm{Cu}-\mathrm{Pb}-\mathrm{Zn}-\mathrm{Ag}-\mathrm{Ba}$ deposits is intriguing. Exploration strategies and techniques in this environment would necessarily be indirect, innovative and expensive (including high resolution seismic surveys). Depth, exploration expense and historical mining problems are obvious major challenges.

\section{Nova Scotia farm well water quality assurance study}

\author{
D. Briggins \\ Nova Scotia Department of the Environment, P.O. Box 2107, Halifax, Nova Scotia B3J 3B7, Canada \\ D. Moerman \\ Nova Scotia Department of Agriculture and Marketing, P.O. Box 550, Truro, Nova Scotia B2N 5E3, Canada \\ and \\ R. Rowe \\ Nova Scotia Department of Health and Fitness, 136 Exhibition Street, Kentville, Nova Scotia B4N 4E5, Canada
}

As part of ongoing environmental monitoring and research efforts of the Nova Scotia Government, the departments of Environment, Agriculture and Marketing, and Health and Fitness are conducting a cooperative study of rural well water supplies in Kings County. Initiated in 1988 this project is designed to assess the quality of drinking water supplies in the intensively farmed areas of the county. As one component of this study, 234 randomly selected wells were sampled in the summer and fall of 1989 to obtain an overview of water quality in the study area. Of these, 98 wells were tested for a range of pest control products, inorganic parameters, and bacteria, and 136 wells were tested for inorganic parameters only.
The results of this survey show that nitrate levels and bacteria counts in a small number of wells exceed the limits established under the Guidelines for Canadian Drinking Water Quality, $12.4 \%$ and $7.1 \%$ respectively. Initial indications are that well depth and soil texture appear to play a significant role in determining which wells exceed the guidelines. Shallow wells in sandy soils are far more likely to have high levels of nitrate than deep wells in heavier textured soils. Trace amounts of pesticides have also been found in some wells; however, the levels detected are well below safe drinking water limits established under the Guidelines for Canadian Drinking Water Quality and in many cases approach the lower detection limits of the analysis. 
During the next two years the project will focus on determining the sources of pesticide, nitrate and bacterial contamination, factors contributing to the movement of these contaminants into well water supplies, and management practices that can be implemented to help maintain the quality of drinking water supplies within the intensive agricultural areas of Nova Scotia.

Clean Water Act of New Brunswick and municipal wellfield protection program

\author{
R.A. Brinsmead \\ Land and Water Planning Section, New Brunswick Department of the Environment, \\ P.O. Box 6000, Fredericton, New Brunswick E3B 5H1, Canada
}

The Clean Water Act of New Brunswick (1989) provides for the designation as a protected area of any watershed, aquifer or groundwater recharge area that is used as a water source for a public water supply. Within a protected area, the Minister of the Environment may impose prohibitions or controls on any activity, thing, land use or water use that might impair the quality or quantity of water, and may allocate the use of water and promulgate standards to protect water quality and quantity.

The New Brunswick Department of the Environment has recently initiated a Wellfield Protection Program, intended to design protection areas encompassing municipal water wells and wellfields. The process involves the issuance to consultants of a Request for Proposals to prepare a Wellfield Protection Plan and Designation Document. The intention is to conduct studies first on municipalities whose wellfields have been judged to be the most vulnerable to contamination and/or the most costly to replace, and to continue working by order of priority through the remaining wellfields.

The process is designed to outline "staged" protection areas, with an inner zone where all hazardous land uses are excluded, and one or more additional zones, the outer boundary of which is suggested to be based on the distance of calculated ten-year groundwater travel time to the well(s) under normal operating conditions. The consultant is expected to prepare a map of the wellfield depicting all existing land uses, and past hazardous land uses, and to assess likely future land-use pressures. Annual recharge and annual safe yield of the wellfield are to be estimated, and a list prepared of excluded and conditioned land uses for each zone. The procedure involves preparation of a public information package, and the holdings of a public meeting to describe the progress and solicit input. The consultant is to outline an appropriate program for implementation of the protective measures, recommend procedures and assess associated costs.

\title{
Halifax Harbour: the sedimentary record of a century of contamination
}

\author{
D.E. Buckley \\ Atlantic Geoscience Centre, Bedford Institute of Oceanography, Dartmouth, Nova Scotia B2Y 4A2, Canada
}

Halifax Harbour has received untreated sewage, solid waste, and industrial byproducts for more than 100 years. Recent research has shown that the sediments in the harbour have retained an imprint of deteriorating environmental quality over the past century. Metals such as $\mathrm{Cu}, \mathrm{Zn}, \mathrm{Pb}$ and $\mathrm{Hg}$ increased in concentration from 1890 to 1970 to reach levels as high, or higher than several other polluted marine harbours around the world. Since 1970 the concentration of these metals in Halifax Harbour sediments has decreased, indicating the effect of decreasing industrial, domestic and institutional use of these toxic metals. Similar trends in the time-stratigraphic record of organic contaminants in a single core from the Northwest Arm of Halifax
Harbour have also been found. Aromatic hydrocarbon combustion products, including PAH's, reached maximum concentrations in the 1950's and have declined in the last 35 years, probably as a result of a shift away from coal and wood fuels in the Halifax urban area. Other pollutant hydrocarbons, such as aliphatic compounds characteristically derived from sewage and urban runoff, have steadily and exponentially increased in concentration over the past 100 years. These sedimentary records of contaminant accumulation clearly demonstrate the impact of past waste disposal practices and point the way toward improved environmental management in Halifax Harbour.

\section{An occurrence of subsilicic orthopyroxene and Opx-Sp-Ru-Qtz assemblage in xenoliths of the Tangier Dike, southern Nova Scotia \\ A.K. Chatterjee and P.S. Giles \\ Nova Scotia Department of Mines and Energy, P.O. Box 1087, Halifax, Nova Scotia B3J 2X1, Canada}

Sapphirine-bearing granulite xenoliths of metasedimentary parentage from Tangier contain abundant subsilicic orthopyroxenes $\left(\mathrm{Si}^{+4}<1.75\right.$ per formula unit) in domains made up of unexsolved ternary feldspars, sapphirine, gamet, spinel, rutile and quartz. Subsilicic orthopyroxenes and the assemblage Opx-
Sp-Ru-Qtz have been predicted through experimental and petrogenetic consideration to occur in rocks of appropriate bulk composition subjected to temperatures exceeding $1000^{\circ} \mathrm{C}$ and pressures approaching $10 \mathrm{~Kb}$. The Tangier granulites provide a rare opportunity to compare theoretically predicted mineral 
assemblages and petrogenetic relationships with naturally occurring assemblages, in turn permitting a rigorous assessment of $\mathrm{P}$ $T$ history of these rocks normally unattainable due to their rarity at the earth's surface.

Petrogenetic considerations at $1100^{\circ} \mathrm{C}$ and $11.7 \mathrm{~Kb}$ predict a decreasing Xmg for $\mathrm{Fe}-\mathrm{Mg}$ minerals in the assemblage from sapphirine through orthopyroxene, spinel and finally garnet. The Tangier data closely match theoretical predictions (Xmg Sa 0.80, Xmg Opx 0.71, Xmg Sp 0.57; and Xmg Gt 0.56). The Xmg value for garnet should theoretically approximate the Xmg of the bulk rock. In the Tangier assemblages, this relationship is confirmed. With an equilibrium temperature of $1000^{\circ} \mathrm{C}$ independently pro- vided by ternary feldspars, the Tangier data strongly corroborate the experimental predictions.

The uniqueness of these sapphirine-bearing xenoliths with their unusual mineral assemblages lies mainly in their preservation at surface, possible only through very rapid rise to high crustal levels. Equally important is the recognition that these represent sedimentary rocks deposited in a presumably normal range of sedimentary environments, and subsequently transported to lower crustal depth within the stability field of pyrope. They are therefore very much "natural rocks" that have experienced crustal conditions far more extreme than most rocks exposed at surface.

\title{
U-Th-Pb systematics of the South Mountain Batholith, Nova Scotia
}

\author{
A.K. Chatterjee and L.J. Ham \\ Nova Scotia Department of Mines and Energy, P.O. Box 1087, Halifax, Nova Scotia B3J 2X1, Canada
}

Elemental concentrations of $\mathrm{U}, \mathrm{Th}, \mathrm{Pb}$ and $\mathrm{Pb}$ isotopic compositions for 34 samples were determined to assess the age, mobility of elements and source rock reservoirs for the peraluminous granitoids of the South Mountain Batholith. The concentrations (ppm) of $\mathrm{U}, \mathrm{Th}$ and $\mathrm{Pb}$ range from 1.510-28.780, 1.48318.403 and $2.25-24.87$, respectively, and the measured $206,20,208 \mathrm{~Pb} /$ ${ }^{204} \mathrm{~Pb}$ isotopic ratios range from $18.627-51.945,15.621-17.422$ and 38.319-42.625, respectively. Whole rock-mineral separates from a granodiorite and a sample of leucogranite from two different plutons within the batholith were analysed isotopically to constrain the age of the least- and most-evolved phases of the body. The granodiorite yields a $\mathrm{Pb}-\mathrm{Pb}$ age of $373.3 \pm 3.6 \mathrm{Ma}$ (MSWD 2.85, 2 sigma) and the leucogranite yields a $\mathrm{Pb}-\mathrm{Pb}$ age of $365.2 \pm 5.4 \mathrm{Ma}$ (MSWD 2.57, 2 sigma). Both ages are considered, within the limits of error, to be identical to the published $\mathrm{Rb}-\mathrm{Sr}$ whole-rock age of $371.8 \pm 2.2 \mathrm{Ma}$ for the batholith.

Regression of the $\mathrm{Pb}-\mathrm{Pb}$ data intersects the $\mathrm{Pb}$ growth curve to give ${ }^{206} \mathrm{~Pb} /{ }^{204} \mathrm{~Pb}$ and ${ }^{207} \mathrm{~Pb} /{ }^{204} \mathrm{~Pb}$ ratio values of $18.143-18.139$ to 15.601-15.600, respectively. These values are close to isotopic values of galena from a granodiorite $(18.141,15.603,38.209$ for ${ }^{206,207,208} \mathrm{~Pb} /{ }^{204} \mathrm{~Pb}$, respectively). Thus, the initial composition of lead at the time of emplacement of the batholith was close to the compositions of galena.

The whole-rock isotopic data, when corrected for common lead, plot on $\mathrm{a}^{206} \mathrm{~Pb} /{ }^{238} \mathrm{U}-{ }^{207} \mathrm{~Pb} /{ }^{235} \mathrm{U}$ diagram and intersect the concordia at near zero and $369 \mathrm{Ma}$ ( 2 sigma). The distribution of points on the concordia diagram is interpreted to reflect loss of uranium during the post-magmatic stage (i.e., a loss of volatiles). Isotopic data in these uranium-lead and thorium-lead diagrams suggest that uranium has been relatively immobile since the time of intrusion and that the apparent $\mathrm{Th} / \mathrm{U}$ ratios were generated as part of the magmatic evolution.

Isotopic data $\left({ }^{206} \mathrm{~Pb} /{ }^{204} \mathrm{~Pb}\right.$ and $\left.{ }^{201} \mathrm{~Pb} /{ }^{204} \mathrm{~Pb}\right)$, corrected to the age of intrusion, yield a linear array, interpreted to be a secondary isochron, which we interpret to represent the age of the protolith $(669 \pm 131 \mathrm{Ma})$. Potential protoliths include Meguma Group metasedimentary rocks, Liscomb gneisses and Tangier metasedimentary and mafic granulites, but the granulites cannot accommodate the total range of the ${ }^{208} \mathrm{~Pb} / 04 \mathrm{~Pb}$. We suggest that the magma for the South Mountain Batholith is granulite-derived and contaminated with the Liscomb gneisses (with minor contribution from Meguma Group rocks) prior to crystallization.

\section{Variations in LIL elements, HFS elements and REES within the Davis Lake Pluton, southwestern Nova Scotia}

\author{
A.K. Chatterjee and R.J. Horne \\ Nova Scotia Department of Mines and Energy, P.O. Box 1087, Halifax, Nova Scotia B3J 2X1, Canada
}

The Davis Lake Pluton (DLP) is a large $\left(816 \mathrm{~km}^{2}\right)$, tilted mushroom-shaped intrusion occupying the southwestern end of the South Mountain Batholith. Coarse-grained monzogranite is the dominant lithology of the DLP with minor fine- to mediumgrained leucomonzogranite (2-6\% mafic minerals) and leucogranite ( $<2 \%$ mafic minerals) exposed in the westernmost lobe of the DLP along the contact with Lower Paleozoic metasedimentary rocks of the Meguma Group.

The DLP displays pronounced continuous and discontinuous cryptic chemical zonation. For example, the $\mathrm{K} / \mathrm{Rb}$ ratio shows continuous variation from $>200$ to $<50$. Present day measured whole-rock uranogenic lead isotopic ratios and LREE's show similar variation with the least evolved rocks of the DLP (K/Rb from 204 to 244) having LREE's ranging from 143 to 212 and ${ }^{206} \mathrm{~Pb} /{ }^{204} \mathrm{~Pb}$ ratios between 18.627 and 18.884 and the most evolved rocks $(\mathrm{K} / \mathrm{Rb}$ ratios $<50)$ having $\Sigma R E E$ 's ranging from 22 to 48 and ${ }^{206} \mathrm{~Pb} /{ }^{204} \mathrm{~Pb}$ ratios ranging from 27.742 to 51.945 . Elemental pairs such as $\mathrm{Zr}-\mathrm{Ta}$, Ti-Zrand $\mathrm{K} / \mathrm{Rb}$-Rb/Sr ratios show continuous co-variation. Marked discontinuity is shown by other elements such as $\mathrm{Y}, \mathrm{Th}$ and $\mathrm{Nb}$, and also ${ }^{208} \mathrm{~Pb} /{ }^{04} \mathrm{~Pb}$ isotopic ratios. Spatial discontinuities occur in a zone which is characterized by granitoid rocks with a $\mathrm{K} / \mathrm{Rb}$ ratio between 50-100. 
Distinctive geochemical trends are recognized in some of the data such that two groupings are made: group 1 is characterized by $\Sigma R E E$ 's from 66 to $152 \mathrm{ppm}(\mathrm{x}=111)$ and $(\mathrm{La} / \mathrm{Yb})_{\mathrm{r}}$ ratios from 1.71 to $2.74 \mathrm{ppm}(\mathrm{x}=2.23)$; group 2 is characterized by $\Sigma R E E$ 's from 40 to $75 \mathrm{ppm}(\mathrm{x}=55)$ and $(\mathrm{La} / \mathrm{Yb})_{\mathrm{N}}$ ratios from 4.00 to 8.08 ( $\mathrm{x}=5.28)$.

The regional chemical and isotopic variations within the
DLP cannot be explained by assimilation/fractional crystallization of a single magma or subsequent deformation and attending hydrothermal alteration of the pre-existing rocks. The most plausible explanation for the observed variation is the presence of two distinct peraluminous magmas derived from a heterogeneous source region.

\title{
Contrasting greisens and associated granitoid rocks of the Davis Lake Pluton:
} implications for the origin of the East Kemptville tin deposit, Nova Scotia

\author{
A.K. Chatterjee and M.A. MacDonald \\ Nova Scotia Department of Mines and Energy, P.O. Box 1087, Halifax, Nova Scotia B3J 2X1, Canada
}

Muscovite-rich ( $\left.\mathrm{K}_{2} \mathrm{O}=3.21-4.33 \mathrm{wt} . \%\right)$ polymetallic quartztopaz greisens (0.16-1.78\% Sn) at the East Kemptville tin deposit and other greisen veins hosted within the leucogranites of the Davis Lake Pluton (DLP) are characterized by low $\mathrm{K} / \mathrm{Rb}(<50)$, high $\mathrm{Rb} / \mathrm{Sr}(>84)$ and high average concentrations of $\mathrm{F}(1.6 \%), \mathrm{Li}$ (830 ppm) and $\mathrm{Rb}(1060 \mathrm{ppm})$. Published analyses of the greisens together with the present data define two distinct U-enrichment trends in the U-Th-Y temary system. The two trends are essentially due to different $\mathrm{Th} / \mathrm{U}$ and $\mathrm{Th} / \mathrm{Y}$ ratios with similar but changing $U / Y$ ratio. The concentration of 14 REE's and $(\mathrm{La} / \mathrm{Yb})_{\mathrm{N}}$ ratios for the greisens and associated granitoids also show two distinct groupings for each rock type. Two distinct trends are also recognized for greisen, leucogranite and leucomonzogranite in the ${ }^{206} \mathrm{~Pb} /{ }^{204} \mathrm{~Pb}$ vs ${ }^{208} \mathrm{~Pb} /{ }^{204} \mathrm{~Pb}$ diagram. However, linear variations in ${ }^{208} \mathrm{~Pb} /{ }^{24} \mathrm{~Pb}$ vs ${ }^{232} \mathrm{Th} /{ }^{204} \mathrm{~Pb}$ and ${ }^{238} \mathrm{U} /{ }^{204} \mathrm{~Pb}$ vs ${ }^{206} \mathrm{~Pb} /{ }^{204} \mathrm{~Pb}$ diagrams imply immobility of $\mathrm{U}$, Th and $\mathrm{Pb}$ since the time of crystallization and greisenization.
The most significant feature of the data set is the remarkable collinearity in the ${ }^{206} \mathrm{~Pb} /{ }^{204} \mathrm{~Pb} v{ }^{207} \mathrm{~Pb} /{ }^{204} \mathrm{~Pb}$ diagram for the greisens and associated leucogranitoids. Greisens from both trends define a slope of 0.053872 (S.D. 0.000065) and a corresponding age of $365.7 \pm 2.7 \mathrm{Ma}$ (MSWD 1.95, 2 sigma). The combination of leucogranite and greisen together defines a slope of 0.053879 (S.D. 0.000066) corresponding to an age of $366.0 \pm 5.6 \mathrm{Ma}$ (MSWD 1.79, 2 sigma). We conclude that greisen and leucogranite are of similar ages and are not 40 Ma younger than the remainder of the South Mountain Batholith as previously suggested. We argue that separate greisen fluids were probably derived from two distinct peraluminous magmas derived from an heterogeneous source, and that the East Kemptville tin deposit probably owes its origin to mixing of these fluids under postmagmatic conditions. The heterogeneous source for the DLP magma(s) was probably characterized by a significantly higher ${ }^{238} \mathrm{U} /{ }^{20} \mathrm{~Pb}$ ratio than the average orogene.

\section{Potential source rocks for gold in Meguma-hosted auriferous vein deposits, Nova Scotia}

\section{A.K. Chatterjee and P.K. Smith Nova Scotia Department of Mines and Energy, P.O. Box 1087, Halifax, Nova Scotia B3J 2X1, Canada}

Initial $\mathrm{Sr}$ (carbonate) and $\mathrm{Pb}$ (galena) isotopic ratios from auriferous vein deposits hosted in Cambro-Ordovician Meguma Group rocks provide constraints regarding origin and potential metal source in the deposits. The $\mathrm{Sr}_{\mathrm{i}}$ of carbonates range from 0.7079 to 0.7156 and ${ }^{206,207,208} \mathrm{~Pb} / 204 \mathrm{~Pb}$ for galena range from 17.191 to $18.568,15.483$ to 15.643 and 36.767 to 38.309 , respectively. Large variations in radiogenic isotopes are present within individual deposits (e.g., Moose River, Goldenville). The observed variations and radiogenic tendencies cannot be attributed to stratigraphic position or proximity to exposed intrusions. The ranges of calculated $\mathrm{Sr}_{\mathrm{i}}$ and ${ }^{206} \mathrm{~Pb} /{ }^{204} \mathrm{~Pb}$ at $372 \mathrm{Ma}$ for various groups of metamorphic and intrusive rocks are given in Table 1.
It is clear that neither the Meguma Group alone nor any combination of Meguma Group metasedimentary rocks and DevonoCarboniferous intrusions can accommodate the ranges of observed initial $\mathrm{Sr}$ and $\mathrm{Pb}$ isotopic ratios in the vein deposits. Alternatively, the Liscomb gneisses could potentially be the sole source for the observed ratios and hence, also for the hydrothermal fluids from which the quartz veins formed. In summary, these isotopic data indicate that the Meguma Group can be eliminated as the sole consideration to the auriferous veins via a metamorphogenic model and that a fluid/metal source within the Liscomb gneiss rocks is more probable.

Table 1

Gold deposits $(\mathrm{N}=20)$

Meguma Group ( $\mathrm{N}=12$ )

Liscomb gneisses $(\mathrm{N}=10)$

Felsic sed. granulites $(\mathrm{N}=17)$

Mafic granulites $(\mathrm{N}=11)$

SMB: Magmatic $(\mathrm{N}=21)$

Liscomb granite $(\mathrm{N}=3)$

Liscomb mafic intrusions $(\mathrm{N}=7)$

Lamprophyre dyke, Tangier $(\mathrm{N}=3)$

$\begin{array}{cc}{ }^{87} \mathrm{Sr} /{ }^{86} \mathrm{Sr} & { }^{206} \mathrm{~Pb} / 204 \mathrm{~Pb} \\ \text { irt at } 372 \mathrm{Ma} & \text { irt at } 372 \mathrm{Ma} \\ & \\ 0.7079-0.7156 & 17.191-18.568 \\ 0.7113-0.7177 & 17.632-18.277 \\ 0.7060-0.7165 & 16.365-18.506 \\ 0.7046-0.7088 & 18.507-18.954 \\ 0.7028-0.7051 & 18.124-19.194 \\ 0.7076-0.7094 & 18.141-19.154 \\ 0.7080-0.7090 & 18.411-18.435 \\ 0.7031-0.7078 & 17.599-18.566 \\ 0.6994-0.7067 & 18.334-18.771\end{array}$




\title{
Effects of natural organic acids on determining the inorganic chemistry of freshwaters
}

\author{
T.A. Clair \\ Conservation and Protection Service, Environment Canada, P.O. Box 861, Moncton, New Brunswick E1C 8N6, Canada
}

\begin{abstract}
Thirty-five lakes located in southern Labrador were sampled in 1989 as part of Environment Canada's acid precipitation monitoring program. Water chemistry values were compared to those from a similar sampling conducted in 1981. Results showed increases in $\mathrm{pH}$, specific conductance, ANC, colour and base cations between the two dates, though sulphate, the ion most likely to reflect acid precipitation, did not vary. The major ion changes are probably due to climatic variations, as river discharge amounts were much lower in 1989 than in 1981.
\end{abstract}

Results showed a slight but significant decrease in water sulphate concentration trend from western to eastem Labrador, though most values, even in the western portion of the study area, fell close to the values considered "background". Assuming little accelerated weathering caused by acid precipitation in this region, and assuming that weathering exceeding that predicted from carbonate effects is due to natural organic acids, then mineral dissolution by natural organic acids ranges between 9 and $52 \%$ of the total.

\section{Sedimentation at the Appalachian thrust front, Port Au Port Peninsula, western Newfoundland}

\author{
R. Corney, J.W.F. Waldron \\ Department of Geology, Saint Mary's University, Halifax, Nova Scotia B3H 3C3, Canada \\ and \\ G.S. Stockmal \\ Geological Survey of Canada, Atlantic Geoscience Centre, P.O. Box 1006, Dartmouth, Nova Scotia B2Y 4A2, Canada
}

Sediments of the Port au Port Peninsula, located on the west coast of Newfoundland, record the evolution and destruction of a Cambrian-Ordovician passive continental margin. Middle Ordovician clastics of the Goose Tickle Group were deposited in advance of the Humber Arm Allochthon. Outcrops in Victors Brook have been interpreted as blocks of Goose Tickle Group material incorporated by the advancing allochthon; we interpret the allochthon-derived material in this area as rafts incorporated into the Goose Tickle Group by sedimentary processes.

Based on fieldwork in the Victors Brook area, a succession upward from carbonate platform through shales to clastics of the Goose Tickle Group has been mapped. The Goose Tickle Group sediments contain conglomerates that have been subdivided into three types: the first type is composed largely of sub-rounded limestone clasts in a fine-grained mud matrix; the second consists of black and green shale chips; and the third is polymictic and poorly sorted, with cobbles and boulders of limestone, dolostone, chert, sandstone, and detrital pyrite probably derived from the Humber Arm Allochthon. A large (150 m) raft, and numerous small blocks of material from the Humber Arm Allochthon have been incorporated into the conglomerates. Sandstones and shales interbedded with the conglomerates show partial Bouma sequences and indicate deposition by turbidity currents. Middle Ordovician graptolites were found in the shales.

Comparison of the Victors Brook section with adjacent areas suggests that the Goose Tickle Group in the western Port au Port Peninsula was deposited in a fault-bounded sedimentary basin formed in front of the advancing allochthon. The basin was structurally inverted during later deformation of probable Devonian ("Acadian") age.

\section{Structural features map in the Magdalen Basin, from seismic reflection data}

\author{
P. Durling and F. Marillier \\ Geological Survey of Canada, Atlantic Geoscience Centre, P.O. Box 1006, Dartmouth, Nova Scotia B2Y 4A2, Canada
}

We present a structural features map that integrates our previous work with a new study of the Windsor Group and older rocks beneath the eastern Magdalen Basin.

We identified three upper crustal blocks in the northwestern part of the Magdalen Basin (Laurent, Bradelle, and Shediac) based on their seismic character and orientation of geological structures. The blocks cannot be mapped east of the Magdalen Islands because their structures are not seen on the seismic data northeast of the Magdalen Islands and Newfoundland. Two large Horton Group subbasins may be represented by thick pre-Windsor Group strata in the Northumberland Strait and near the Magdalen Islands. A major fault zone that affects the Carboniferous rocks extends from eastern Northumberland Strait to
Newfoundland and defines the southeastem limit of the Magdalen Basin.

Southeast of the Magdalen Islands, pre-Carboniferous basement extends beyond the record length of the industry seismic profiles $(6 \mathrm{sec}$.). In this area, there is extensive Windsor Group salt tectonics. Beneath the salt, but generally above the basal Windsor Group horizon, rocks of largely unknown nature (but possibly of Horton Group age and older) are present. The absence of faults bounding the basin to the northwest and the deformation suffered by the Carboniferous rocks in this area suggests that the rocks underlying the salt may have been tectonically emplaced during post-Windsor Group compression. 
Tectonic significance of the St. Croix Terrane, southwestern New Brunswick

\author{
L.R. Fyffe \\ Mineral Resources, Department of Natural Resources and Energy, \\ P.O. Box 6000, Fredericton, New Brunswick E3B 5H1, Canada
}

The St. Croix Terrane in southwestern New Brunswick and adjacent Maine is underlain by the Ordovician Cookson Group. From the base upward, the Cookson Group comprises black pelites of the Calais Formation, wackes of the Woodland Formation, and quartz arenites of the Kendall Mountain Formation. The Digdeguash Formation, previously assigned to the Silurian, is considered to be equivalent to the Woodland Formation on the basis of lithological similarities. The Calais and Kendall Mountain formations, respectively, contain Tremadocian and Caradocian graptolites. Deformed plutons presumably of Early Silurian age (U-Pb dating is in progress), and massive Late Silurian to Early Devonian and Late Devonian plutons intrude the stratigraphic sequence.

The variation in attitude of bedding in the St. Croix Terrane area can be attributed to at least three, approximately co-axial generations of folding. The first and second folds are generally tight and are associated with penetrative, axial planar cleavages, whereas the third folds are open folds or kinks without an associated penetrative cleavage. Multiple episodes of high-grade metamorphism appear to coincide with the emplacement of various intrusions during distinct stages of structural development.

The compressive structural features within the St. Croix Terrane resulted from continental collision between the Avalon Terrane and North America. This collisional event must have begun after deposition of the continental rise deposits of the Cookson Group, i.e., after the Caradocian (mid-Ordovician). Debris-flow deposition along the St. Croix-Avalon boundary, recorded in the Late Silurian Oak Bay Formation, presumably reflects tectonic uplift at high crustal levels during continental convergence. Low-pressure metamorphism and generation of syn- to post-tectonic, bimodal magmatism in the St. Croix Terrane suggests a relatively slow rate of lithospheric thickening involving both crust and upper mantle. Such a model is consistent with the extended age range (greater than $50 \mathrm{Ma}$ ) of plutonism in the region.

SEM study on the cuticular structure of some medullosan foliage from the Upper Carboniferous of the Sydney Coalfield

\author{
Z. Gao and E.L. Zodrow \\ Department of Geology, University College of Cape Breton, Sydney, Nova Scotia B1P 6L2, Canada
}

Cuticle is a waxy layer on the surface of plants. Study on fossil plant cuticles has greatly advanced the understanding of the Plant Kingdom in the geological past. After the light microscopy study on the cuticles of Neuropteris foliage from the Upper Carboniferous of the Sydney Coalfield, cuticle samples have been prepared for scanning electron microscopy examination. The results are surprisingly different from those of light microscopy interpretations, particularly, the stomatal apparatus. Hence, the new information provides a better understanding of the paleoecology of these plants.

\title{
Coticules: significance to stratigraphic and metallogenic studies in the northern Appalachians
}

\author{
W.W. Gardiner and D.V. Venugopal \\ Department of Natural Resources and Energy, P.O. Box 6000, Fredericton, New Brunswick E3B 5H1, Canada
}

Coticules are defined as manganiferous quartzites rich in spessartine garnet. They are believed to represent fine-grained metamorphosed manganese- and hematite-rich sediments that are commonly of an exhalative origin. Coticules have been recorded throughout the Appalachian-Caledonian Orogen in rocks of Early Ordovician age. However, rocks of similar composition described as 'garnetites', 'quartz-bearing garnetite', and 'garnet envelope', have been documented at various stratigraphic ages in other parts of the world. The apparent time-constrained nature of the Appalachian-Caledonian coticules is believed to provide a key to stratigraphic and tectonic correlation on both sides of the orogenic belt.

The coticule occurrences in New Brunswick are now being documented both in the Tetagouche Group in the central and northern parts of the province and in the Cookson Group in the southern part of the province. They represent metamorphosed manganese formations such as the red manganese siltstones and shales (locally termed RMS) that contain high levels of a number of trace metals including Sn, W, Au and As.

The coticule-bearing horizons lie at about the same stratigraphic level (which may be time-transgressive to the southwest) as the Bruns:vick base-metal horizon and hence may be the facies equivalent of the massive sulphide deposits. The formation of coticules along with their associated rock types, such as tourmalinites, are being examined in the light of their relationship to massive sulphide, stratiform scheelite greywacke-hosted gold and other mineral deposits. 
The structural evolution of the northern segment of the Dunnage/Gander zone boundary, Newfoundland

\author{
L.B. Goodwin \\ Centre for Deformation Studies in the Earth Sciences, Department of Geology, University of New Brunswick, \\ Fredericton, New Brunswick E3B SA3, Canada \\ and \\ P.P. O'Neil \\ Department of Mines and Energy, Geological Survey Branch, St. John's, Newfoundland A1B 4J6, Canada
}

Detailed mapping and structural analysis of key areas, including investigation of sense-of-shear indicators, has been carried out along the Dunnage/Gander zone boundary. The portion of the boundary studied separates the Exploits Subzone from the Gander Lake Subzone between Gander Lake to the south and Musgrave Harbour to the north.

Deformation events recorded by structures along and adjacent to the boundary can be divided into three groups. The oldest structures for which kinematic indicators exist developed through ductile strike-slip and oblique-slip motion. Dextral predated sinistral displacement; more than two episodes of ductile strikeslip and oblique-slip movement may have occurred. Structural features in rocks along the shores of Ragged Harbour indicate that some of the movement was contemporaneous with Siluro-
Devonian plutonism.

Low-angle normal motion resulted in the development of mylonite that overprints structures developed during strike-slip and oblique-slip motion. The relative timing of low-angle normal ductile shear and ductile-brittle to brittle faulting is unknown. The latter postdates the cooling of a Devonian granite, but is otherwise unconstrained in age. Notable among the brittle faults are northerly trending normal faults and the most common westerly to northwesterly trending dextral strike-slip faults. Both sets may be related to Atlantic opening.

We suggest that the present form of the Exploits/Gander Lake subzone boundary is largely the result of at least two episodes of strike-slip and oblique-slip motion.

\title{
Seismic study of bedrock geology, Gulf of St. Lawrence region
}

\author{
A.C. Grant \\ Geological Survey of Canada, Atlantic Geoscience Centre, P.O. Box 1006, Dartmouth, Nova Scotia B2Y 4A2, Canada \\ and \\ B.V. Sanford \\ 17, Meadowglade Gardens, Nepean, Ontario K2G 5J4, Canada
}

Cruises to the Gulf of St. Lawrence by the Atlantic Geoscience Centre since 1971 have recovered approximately 14,000 $\mathrm{km}$ of high resolution (single channel) reflection seismic profiles. These data are being analysed in conjunction with some 40,000 $\mathrm{km}$ of industrial multichannel seismic records. The integrated interpretation of these two data sets is proving to be a fruitful approach, because the high resolution seismic techniques provide good records for the shallow part of the section that is poorly resolved by the deep penetration industry data. The "hard bottom" conditions that present problems in multichannel shooting are especially severe in the Anticosti Basin portion of the Gulf.

Objectives of this project are to produce a revised map of bedrock geology, and subsurface structure and isopach maps. A preliminary result indicated by synthesis of these two data sets is that Carboniferous strata of the Magdalen Basin may extend somewhat farther northward than previously recognized. In the northwestem part of the Gulf this may superimpose potential trap and reservoir sequences on source rocks of the Anticosti Basin, and present targets for hydrocarbon exploration.

Involvement of petroleum in the genesis of the Jubilee $\mathrm{Zn}-\mathrm{Pb}$ deposit, Cape Breton Island

\author{
M.C. Graves \\ Cuesta Research Limited, 154 Victoria Road, Dartmouth, Nova Scotia B3A 1V8, Canada \\ and \\ F.J. Hein \\ Department of Geology, University of Calgary, Calgary, Alberta T2N 1N4, Canada
}

Stratabound zinc and lead mineralization occur at Jubilee in brecciated Carboniferous limestone (at least 500,000 tonnes in excess of $6 \% \mathrm{Zn}-\mathrm{Pb}$ ). The footwall of the Jubilee deposit consists of conglomerate (Horton Group) overlain by laminated limestone (Macumber lithology, Windsor Group). The hanging wall is massive anhydrite (Windsor Group). There is thicker limestone breccia along the Jubilee Fault. Laterally this brecciated limestone passes into an interlaminated anhydrite-limestone unit. The breccia is a secondary deposit formed by solution of anhydrite from this interbedded zone, which resulted in a "reaccumulation" of undissolved limestone fragments.

Vug fillings, joint coatings, and fluid inclusions of liquid hydrocarbons and bituminous matter are ubiquitous in drill-core. It is particularly common in zones of both high present porosity 
1990). Crustal thickness should also correlate with water depth at the time the crust is formed; crustal thickness as well as crustal chemistry and initial crestal depth depends on mantle temperature. We cannot test this hypothesis directly using observations from present active ridge crests where crust is still segregating from the mantle. Consequently we adopt the technique used by Keen, Klein and Melson, restoring sites where crustal thickness has been measured to their initial crestal depths, to show that crustal thickness as well as crustal chemistry correlates with the original water depth at the time of crustal formation.

\title{
Ichnology of non-marine Carboniferous strata between Cheticamp and Inverness, northwestern Cape Breton Island, Nova Scotia
}

\author{
D.G. Keighley and R.K. Pickerill \\ Department of Geology, University of New Brunswick, Fredericton, New Brunswick E3B 5A3, Canada
}

Non-marine Carboniferous strata in coastal sections of northwestern Cape Breton Island represent the Horton Group, Mabou Formation (Canso Group), Port Hood Formation (Riversdale Group) or Inverness Formation (Pictou Group) from previous maps. Studies have concentrated on the Mabou and Port Hood formations which predominate in this area.

Two major trace fossil localities have been discovered. At Grand Etang, within laminated red siltstones and grey currentrippled, fine-grained sandstones assigned to the Mabou Formation, the trace fossil suite includes Helminthopsis isp., Palaeophycus striatus, Palaeophycus isp., ?Planolites isp., Cruziana problematica, Circulichnis montanus, Rusophycus didymus, Skolithos isp., ?Ancorichnus isp., and several unnamed meniscate burrows, tracks and ? footprints.
The ichnocoenose encountered from similarly interbedded red siltstones and grey sandstones near Broad Cove, in strata previously assigned to the Port Hood Formation, comprises Rusophycus didymus, Cruziana problematica, Helminthopsis isp., Palaeophycus striatus, Stiaria intermedia, Gordia marina, and ?Planolties isp., together with unnamed tracks, ? meniscate burrows and vertebrate footprints.

In both cases, associated raindrop imprints, desiccation cracks and possible soil horizons have confirmed the non-marine origin of the sediments and the trace fossils. The depositional environment of these trace fossil-bearing sediments is interpreted as that of a low energy floodplain, with intermittent sheetflood events, an environment typically representative of the Scoyenia ichnofacies to which this trace fossil suite belongs.

\section{A mineralogical and fluid inclusion study of the West Gore Sb-Au deposit, central Meguma Terrane, Nova Scotia: a possible high-level analogue for mesothermal Meguma Group lode-gold deposits

\author{
D.J. Kontak and P.K. Smith \\ Nova Scotia Department of Mines and Energy, P.O. Box 1087, Halifax, Nova Scotia B3J 2X1, Canada
}

Mineralization at the West Gore Sb-Au deposit (7158 oz. Au produced), hosted by NE-trending slates of the Halifax Formation, occurs within three, subparallel and subvertical, NW-trending fault structures. Vein fill is dominated by unstrained, bimodal quartz (coarse prismatic and fine-grained equant) and paragenetically later carbonate+chlorite and associated ore minerals occupying vugs or orthogonal fracturęs. The ore assemblage consists of early stibnite, locally replacing po, with associated po \pm py \pm arspy \pm Fe-rich sph \pm cpy \pm native antimony. Stibnite occurs either as coarse blebs or delicate, acicular to reticulate grains intergrown with quartz and/or carbonate. Stibnite is replaced by a complex, concentrically zoned intergrowth of native $\mathrm{Au}(<1 \mathrm{wt} . \% \mathrm{Ag}$ ) and colloform-textured $\mathrm{Au}-\mathrm{Cu}$ alloy; this assemblage is frequently accompanied by zones of carbonate \pm chlorite enrichment. The latest stage of mineralization consists of $\mathrm{Fe}$ - and $\mathrm{Mn}$-oxides and secondary $\mathrm{Sb}$ minerals [kermesite $\left(\mathrm{Sb}_{2} \mathrm{~S}_{2} \mathrm{O}\right)$ and valentinite $\left.\left(\mathrm{Sb}_{2} \mathrm{O}_{3}\right)\right]$.
Fluid inclusions (quartz only; $5-15 \mu$ size) occur as (1) isolated groups or (2) planar arrays along healed microfractures. The cores of prismatic-quartz grains are generally inundated with inclusions whereas the margins are inclusion-free; hence, a probable primary or pseudo-secondary origin for the inclusions. Inclusion types are: (i) V-rich $\left(\mathrm{H}_{2} \mathrm{O}\right)$, (ii) L-rich $\left(\mathrm{H}_{2} \mathrm{O}\right)$, and (iii) $\mathrm{H}_{2} \mathrm{O}-\mathrm{CO}_{2}\left(\mathrm{X}_{\mathrm{CO}_{2}}=0.1\right)$. While type (iii) is rare, (i) and (ii) are abundant and their mutual coexistence suggests fluid unmixing. Thermometric data $\left({ }^{\circ} \mathrm{C}\right)$ are summarized as follows: $(1) \mathrm{T}_{\mathrm{m}}\left(\mathrm{CO}_{2}\right)=$ $-58.7 \pm 1.0(\mathrm{n}=8)$; (2) $\mathrm{T}_{\mathrm{m}}$ (ice) $=-4.0 \pm 1.0 \quad(\mathrm{n}=50$; ca. $5-8 \mathrm{wt} . \%$ equiv. $\mathrm{NaCl})$; (3) $\mathrm{T}_{\mathrm{b}}\left(\mathrm{CO}_{2}\right)=25.4 \pm 0.8(\mathrm{n}=4$; to $\mathrm{L})$ and $13.3(\mathrm{n}=1$; to V; and (4) $\mathrm{T}_{b}\left(\mathrm{H}_{2} \mathrm{O}\right)=\mathrm{ca} .200-400(\mathrm{n}=177$; to $\mathrm{L})$ and $370(\mathrm{n}=5$; to $V$ ). In addition, (1) clathrate formation indicates ca. $1 \mathrm{~mol} \%$ dissolved $\mathrm{CO}_{2}$ in type (ii) inclusions, (2) decrepitation is common between $300-400^{\circ} \mathrm{C}$, (3) there is no correlation between salinity and $\mathrm{T}_{b}\left(\mathrm{H}_{2} \mathrm{O}\right)$ and $(4)$ ambient pressure of formation is estimated at $0.6 \mathrm{kbars}$ (ca. $1700 \mathrm{~m}$ lithostratic cover). 


\section{Current research into Carboniferous basin development in western Newfoundland and nearby areas, using geological and geophysical data \\ G.S. Langdon \\ Department of Earth Sciences, Centre for Earth Resources Research, Memorial University of Newfoundland, St. John's, Newfoundland A1B 3X5, Canada}

Recent research in western Newfoundland has involved the interpretation of a newly acquired seismic line over the portion of the Carboniferous basin exposed onshore. These data, in combination with the onshore geological map database, are being applied in an interpretation of the seismic data offshore in the Sydney Basin and eastern Magdalen Basin. We are interested in mapping the shape and distribution of the Carboniferous, and in studying the genesis of small fault-bounded subbasins within the context of large-scale transcurrent faulting and its associated stress regime. In the immediate area this may involve an under- standing of the relationship between the deformation history of slightly older Paleozoic rocks, igneous and associated mineralizing fluid activity during Carboniferous time, and the movement on large-scale lateral faults identified from offshore geophysical data; these aspects are now being investigated from Cape Breton Island across the Cabot Strait to southwestern Newfoundland. It is hoped that any forthcoming results or interpretations could be integrated with similar studies elsewhere to lead to a better understanding of the Maritimes Basin.

\section{Microbial treatment of acidic drainage at Halifax International Airport \\ R.G.L McCready, G. Bechard and S. Rajan \\ CANMET, Energy, Mines and Resources, 555 Booth Street, Ottawa, Ontario K1A 0G1, Canada}

A laboratory model, continuous treatment system has been run for more than fourteen months resulting in a change in $\mathrm{pH}$ from 3.5 to substantial reductions in both the iron and sulphate content of the simulated acidic drainage during treatment. When the laboratory model was scaled up to 550 fold for a field test, results similar to the laboratory tests were observed until mid-
July, 1990, at which time the anaerobic zone, which had developed in the system, was severely disturbed while adding fresh straw to it. The system took about eight weeks to re-equilibrate and is currently showing complete removal of aluminum with an average effluent $\mathrm{pH}$ of greater than 5.0.

\section{Biodegradation of lignite coal tar \\ R.G.L. McCready, S. Rajan, DJ. Barkley, L.A. Pokrajac \\ CANMET, Energy, Mines and Resources, 555 Booth Street, Ottawa, Ontario K1A 0G1, Canada and \\ K.G. Crane \\ Luscar Limited, Edmonton, Alberta TSJ 3G1, Canada}

Through the acquisition of a coal carbonizing facility in southern Saskatchewan, Luscar Limited became responsible for the disposal of $8500 \mathrm{~m}^{3}$ of coal tar on the site. The company has decided to dispose of this material in an economical and environmentally safe manner. CANMET was asked to conduct a feasibility study on the biodegradation of this waste material using a modification of the technology developed for the degradation of refinery slop oils and sludges by a research group within the oil sector.

Initial studies indicated that the coal tar at the periphery of the storage site was intermixed with soil carried in by runoff. Thus about $40 \%$ of the waste material is about $75 \%$ weathered sandstone silt and soil humus and about $25 \%$ coal tar. The remainder is viscous coal tar. Preliminary studies also indicated a substantial population of indigenous bacteria which were capable of degrading the coal tar.

The coal tar sludge was mixed with Oclansorb (a proprietary oil adsorbent) in a ratio of $2: 1$ by weight and placed in a $7.5 \mathrm{~cm}$ $x 75 \mathrm{~cm}$ column. The column was inoculated with a mixed culture of coal tar-degrading bacteria. Moist air was sparged through the mixture at $3 \mathrm{~L} / \mathrm{min}$ and a nutrient medium was trickled through the mixture at $100 \mathrm{ml} / \mathrm{h}$. Weekly samples were collated for organic extraction, recovery and analysis by gas chromatography. The experiment was terminated after eight weeks at which time about $55 \%$ of the coal tar was degraded. 
A previously unrecognized Lower Ordovician sequence in southern New Brunswick: evidence for multistage development of Iapetus?

\author{
M.J. McLeod, A.A. Ruitenberg \\ Department of Natural Resources and Energy, Geological Surveys Branch, \\ P.O. Box 1519, Sussex, New Brunswick EOE 1PO,Canada \\ and \\ T.E. Krough \\ Department of Geology, Royal Ontario Museum, 10 Queen's Park, Toronto, Ontario M5S 2C6, Canada
}

Geological mapping and radiometric studies established the presence of a previously unrecognized, Lower Ordovician bimodal volcanic-sedimentary belt in the Annidale area of southcentral New Brunswick. The belt constitutes the northeastern extension of the St. Croix Terrane and occurs immediately northwest of the Precambrian-Cambrian Avalon Terrane. The stratigraphy of the belt is characterized by a sequence of intensely deformed pillow basalts, mafic and felsic tuffaceous rocks, felsic domes and flows, and thinly bedded, locally carbonaceous, siltstones and slates. Two precise U-Pb dates on zircon from massive and deformed felsic volcanic rocks yielded ages of 493 $\pm 2 \mathrm{Ma}$ and $490 \pm 4 \mathrm{Ma}$ respectively. The structure of the belt is dominated by northward- and southward-directed thrust and steep-dipping strike-slip faults. These structures are mostly attributed to terrane accretion which ceased prior to emplacement of the Late Silurian-Devonian Saint George Batholith. Preliminary chemical data indicate that the belt may represent the vestiges of an accreted island-arc volcanic sequence. If this interpretation is correct, it would be consistent with a multistage evolution of the Iapetus Ocean.

The Bateman Brook Metamorphic Suite at the Aspy/Bras d'Or terrane boundary in the Cape Breton Highlands: intermixed mylonitized blocks of other units?

\title{
D.W.A. McMullin, S.M. Barr and R.P. Raeside \\ Department of Geology, Acadia University, Wolfville, Nova Scotia BOP 1XO, Canada
}

The Bateman Brook Metamorphic Suite is the westernmost unit of the Bras d'Or Terrane in the central Cape Breton Highlands. It outcrops along the Eastern Highlands Shear Zone--the contact between the Bras d'Or Terrane and the Aspy Terrane to the northwest. The Bateman Brook Suite is enigmatic and has been described as mixed quartzofeldspathic and amphibolite gneiss. The nature of its contacts with the adjacent units are not clear but appear to be mainly faulted.

The Bateman Brook Metamorphic Suite includes semipelitic schist, mafic and felsic volcanic rocks, foliated mafic gneiss similar to the adjacent Kath Road Dioritic Suite, and homblendite. It may be a melange of blocks of other units in the area, though it includes some lithologies (e.g., mafic gneiss) unrecognized in other units. Almost all the lithologies are strongly foliated. The foliation in many of the samples is interpreted to be mylonitic and is variably annealed. Some samples show classical mylonitic C-S fabrics, porphyroclasts, ribbon grains and polygonized quartz. Completely annealed samples are recognizable as blastomylonites in hand sample only, either as narrow shear zones of finer grained material in the host lithology, or from macroscopic textures not discernable in thin section. These features indicate that mylonitization, possibly due to movement on the Eastern Highlands Shear Zone, continued over a wide range of P-T conditions and/or over a long period of time.

Understanding the origin of the Bateman Brook Metamorphic Suite is critical to the interpretation of the tectonic relationship of the Bras d'Or and Aspy terranes. It is also of economic importance as it is host to a number of important gold showings.

High-Grade gneisses of the Blair River Complex in the northwestern Cape Breton Highlands

$$
\begin{gathered}
\text { B.V. Miller } \\
\text { Department of Geology, Acadia University, Wolfville, Nova Scotia BOP IXO, Canada } \\
\text { and } \\
\text { Department of Geology, Dalhousie University, Halifax, Nova Scotia B3H 3J5, Canada }
\end{gathered}
$$

The high-grade metamorphic rocks of the Blair River Complex have been particularly problematic in large-scale mapping projects in the northwestern Cape Breton Highlands. Lithologic variations occur over small distances making subdivision of the various units difficult at scales mapped. However, more recent mapping and petrographic study has resulted in the recognition of three distinct lithologies; a paragneissic unit, an orthogneissic unit, and amphibolites as dikes and small bodies. The paragneissic unit is largely recognized on the basis of petrographic study and hence its field relations with other units are unclear. However, the samples recognized as paragneiss occur predominantly along the extreme western, northem and northeastern portions of the Blair River Complex (spatially associated with the presently exposed "edges" of the complex). 
Mineralized carbonate xenoliths of the Meat Cove zinc occurrence also are spatially restricted to the edge of the main body of the Blair River Complex, although it is unclear what relationship, if any, these xenoliths have with the paragneissic unit. This unit has been metamorphosed to at least biotite isograd, and in some areas to garnet isograd. Orthogneisses occupy the vast majority of the core of the Blair River Complex and vary widely in lithology. They are comprised of quartzo-feldspathic and granitic to syenitic gneisses, metamorphosed to upper amphibolite and locally to granulite facies. Further subdivision of this unit is necessary, but not yet possible. Amphibolites occur as dikes and small bodies in the orthogneissic unit, locally making up a significant proportion of the unit.

Problems of vitrinite reflectance in Scotian Basin and its relation to overpressuring and hydrocarbon generation

\author{
P.K. Mukhopadhyay \\ Global Geoenergy Research Limited, P.O. Box 9469, Station A, Halifax, Nova Scotia B3K 5S3, Canada \\ J.A. Wade and M.P. Avery \\ Basin Analysis Subdivision, Atlantic Geoscience Centre, Bedford Institute of Oceanography, P.O. Box 1006, \\ Dartmouth, Nova Scotia B2Y 4A2, Canada
}

Vitrinite reflectance, one of the most useful paleogeothermometers, is often oversimplified resulting in confusion in the solution of important geological problems. The fundamental problem lies in the selection of vitrinite grains and lack of knowledge about the kinetics of vitrinite reflectance related to heat flow and thermal conductivity. In the Scotian Basin, composite profiles of vitrinite reflectance were compiled from thirty boreholes chosen from various locations. These data suggest that the "oil window" as considered from the vitrinite reflectance, is related to sedimentary facies, organic facies, erosional unconformity, and overpressuring. The base of the 'oil window' varies between 4400 to $5700 \mathrm{~m}$. A 'kink' in the vitrinite reflectance profile possibly relates to the initial depth to the top of overpressure. In the overpressured zone, where organic matter is overmature or at the base of the 'oil window', fluorescence of phytoclasts and groundmass bitumen indicates the presence of 'liver oil'. This concept may indicate the presence of more 'deep condensate' in the Scotian Shelf.

\title{
Igneous provinces in the Circum-Atlantic orogens
}

\author{
J.B. Murphy \\ Department of Geology, St. Francis Xavier University, Antigonish, Nova Scotia B2G 1CO, Canada
}

A thermatic map displaying the age, petrogenesis, tectonic setting and composition of igneous rocks in Circum-Atlantic orogens is being prepared as part of Project 233 of the International Geological Correlation Program. The 1:5,000,000 map is being compiled from the contributions of petrologists in eastern North America, Europe, North Africa and northern South America. Terrane boundaries will be modified from the tectonic map of Keppie and Dallmeyer (1989). A provisional legend, timespace diagrams, and examples from several areas are displayed.
The main colour designates the age, and the shade of colour, the tectonic setting. Composition and source are denoted by overlay patterns. Time-space diagrams from various localities are positioned around the map and show the diversity of magmatism in each terrane and the relationships to adjoining terranes. A catalogue that will accompany the map will contain representative analyses from each terrane and references to where the data may be obtained.

\section{Tectonic activity and the development of igneous layering}

\section{J.B. Murphy \\ Department of Geology, St. Francis Xavier University, Antigonish, Nova Scotia B2G 1CO, Canada}

Tectonic activity may be responsible for triggering the development of igneous layering at various levels in a magma chamber. Hypothetical examples are presented associated with dilation of a magma chamber and motion on adjacent faults. Near the roof and floor of the chamber, crystal-rich mushes are capable of transmitting tectonic stress and layering may result in progressive and multiple injection of magmas into fractures developed by brittle failure. In the liquid-rich portion of the chamber, pressure-release associated with dilation of the magma chamber may temporarily reduce pressure exerted by the magma on the host rock. This allows (1) influx of water from the host-rock and volatile fluxing to promote compositional zoning by Soret diffusion or convective fractionation and (2) magma replenishment from a subjacent magma reservoir. If the new magma is less dense, then magma mixing may occur depending on the Reynolds number and the intensity of penecontemporaneous tectonic activity. If the new magma is denser, it will pond at the base of the magma chamber and spread out laterally under the influence of horizontal pressure gradients. Deceleration of the incoming magma leads to a progressively wider static zone and incorporation of crystal nuclei. Growth and deposition of these crystals into layers may be aided by tectonic agitation, which reduces the yield strength and the effective viscosity of the magma. Tectonic agitation may facilitate escape of solute, local fluidization of the layer and rise of less dense crystals to the top of the layer. 
Early Carboniferous hydrothermal events of the western Cobequid Highlands, Nova Scotia

J.D. Nearing

Department of Geology, Saint Mary's University, Halifax, Nova Scotia B3H 3C3, Canada

Qualitative petrological suite analysis, quantitative microprobe, and whole-rock geochemical data are used to document hydrothermal activity in intrusive bodies immediately north of the Cobequid Fault. The plutons concerned with this study are the Cape Chignecto, Hanna Farm, Moose River, and North River plutons. 1:500,000 lithogeochemical and airborne radiometric maps indicate elemental anomalies possibly related to hydrothermal events. In particular, airborne radiometric maps indicate a strong potassic anomaly along the Cobequid Fault. Major hydrothermal activity is characterized by albitization, biotitization, and chloritization. Minor activity is marked by the presence of carbonate, chlorite, rutile-haematite bearing veins. Possible REE mineralization is present within the Cape Chignecto Pluton. REE mineralization is marked by the presence of fluorite and curious isotropic minerals infilling fractures and vugs.

Albitization and biotitization of granites are early high temperature events based upon criteria of formation and crosscutting relationships. Except the North River Pluton, albitization of K-feldspar and perthite is present in all the studied plutons. Biotization occurs in gabbroic bodies of the Cape Chignecto, Hanna Farms, and Moose River plutons. Biotitization of the gabbroic intrusives is primarily the replacement of primary hornblende and biotite by secondary biotite. Biotitization textures within the gabbroic phases can be strongly correlated with those seen in the Santa Rita porphyry copper deposit, New Mexico. Strong biotitization documented in the Santa Rita porphyry is strongly related to potassic alteration. Pervasive potassic alteration may be related to airborne radiometric anomalies along the Cobequid Fault. Chlorization, carbonization, and rutilehaematization are considered late stage events possibly related to mafic dyke emplacement in an extensional environment.

Seismic clues to Carboniferous basin development in the Moncton Subbasin, New Brunswick

\title{
W.A. Nickerson \\ Department of Earth Sciences, Centre for Earth Resources Research, Memorial University of Newfoundland, St. John's, Newfoundland A1B 3X5, Canada
}

The Moncton Subbasin in New Brunswick is a fault-bounded wedge of Upper Devonian to Westphalian, dominantly terrestrial, sediments. Because of its hydrocarbon potential, this subbasin has been the focus of substantial geophysical and drilling activity. Seismic reflection data collected by industry in the Moncton Subbasin has been interpreted in light of revised surface mapping with the goal of better understanding the tectonic evolution of the subbasin. Preliminary results indicate that Carboniferous rocks have undergone at least three distinct phases of deformation in the Permo-Carboniferous: growth faulting along listric normal faults in late Devonian to Tournasian, compression evidenced by basin inversion during late Tournasian or early Visean, and segmentation of the basin by strike-slip faults which have moved since early Westphalian.

Silurian cover, Late Precambrian - Early Ordovician basement and the chronology of Silurian orogenesis in the Hermitage Flexure: implications for gold metallogeny in southwest Newfoundland

\author{
B.H. O'Brien, S.J. O'Brien \\ Geological Survey Branch, Newfoundland Department of Mines and Energy, P.O. Box 8700, \\ St. John's, Newfoundland AlB 4J6, Canada \\ and \\ G.R. Dunning \\ Department of Earth Sciences, Centre for Earth Resources, Memorial University of Newfoundland, \\ St. John's, Newfoundland A1B 3X5, Canada
}

Redefining the La Poile Group as an Early - Late Silurian ( $429 \pm 2 \mathrm{Ma}$ to $422 \pm 2 \mathrm{Ma}$ ) terrestrial volcano-sedimentary succession and establishing its external relationships has led to its recognition as a cover sequence developed upon a basement complex. Basal La Poile Group conglomerate rests nonconformably on Late Precambrian basement granite ( $578 \pm 10 \mathrm{Ma}$ ), which crosscuts undated high-grade amphibolitic gneiss and low-grade sedimentary and volcanic rocks. This composite subLa Poile Group basement also contains early Paleozoic plutonic constituents, the youngest of which is Early Ordovician ( $495 \pm 2$
$\mathrm{Ma})$ in age, that delimit discrete pre-Silurian tectonothermal events within the complex. Early Silurian granites ( $429 \pm 2 \mathrm{Ma}$; $430 \pm 2 \mathrm{Ma}$ ), which are in part synchronous with the accumulation of subaerial cover deposits, are restricted to the sub-La Poile basement and have been affected, in places, by mesozonal synplutonic shear zones. Later Silurian plutons were emplaced syntectonically during regional deformation and dynamothermal metamorphism of the Silurian cover and contemporaneous remobilization of its basement. Thrust imbrication of cover and basement, which was preferentially sited along the fault zones 
that bound the La Poile Group, occurred shortly after deposition, prior to the emplacement of Late Silurian granite porphyry (418 $\pm 2 /-1.5 \mathrm{Ma}$ ). The older Silurian granites and the thrust-imbricated assemblage of basement and cover are crosscut by Late Silurian granite plutons ( $419 \pm 2 \mathrm{Ma}$ ); all have been affected by further inhomogeneous ductile deformation that predates the post-tectonic intrusion of Early Devonian granite (390 $\pm 3 \mathrm{Ma}$ ).

The Silurian La Poile Group and its underlying Late Precambrian - Early Ordovician basement delimit the southern extent of the medial Ordovician Dunnage Zone in the southwest Hermit- age Flexure region of the Newfoundland Appalachians. The subLa Poile basement and its cover, both of which overthrust Dunnage Zone rocks, were variably deformed and metamorphosed during a climactic Silurian orogeny sited along the southeastem crystalline margin of the Newfoundland Central Mobile Belt. The protracted and episodic nature of basementcover interaction and crustal remobilization near this major tectonostratigraphic boundary has important implications for the control and localization of gold mineralization.

Surficial geology of the Nepisiguit Lakes map area, emphasizing till clast composition, Miramichi Highlands, north-central New Brunswick

M.A. Parkhill

New Brunswick Department of Natural Resources and Energy, P.O. Box 50, Bathurst, New Brunswick E2A 3Z1, Canada

Most of the Nepisiguit Lakes map area (N.T.S. $210 / 7$ ) is underlain by Lower Palaeozoic felsic and mafic igneous rocks. The bedrock is covered by a layer $(<2 \mathrm{~m})$ of Late Wisconsinan ablation and basal till or ablation lag over basal till. Around major watercourses, glaciofluvial and alluvial deposits are common. Bedrock and colluvium dominate in steep valleys, and on topographic highs. Preglacial grus is common over granites. Few iceflow indicators and a lack of dateable materials make the sequence of glacial events difficult to define. Striations, grooves, roche moutonnée, pebble counts and a till fabric indicate an early eastward ice movement followed by northeastward and southeastward glacial events. Finally, local ice flowed in various directions, off topographic highs.
Analysis of 100 pebbles from basal till at 264 sites on a $2 \mathrm{~km}$ grid, suggests that till is locally derived and contains few distal clasts. Underlying bedrock comprises $>75 \%$ of pebbles in the till and up to $100 \%$ within large bedrock units. Pebble counts can be useful bedrock-mapping tools in areas of thick overburden and limited outcrop. Although bedrock lithologies show few ice-flow indicators many of them are distinct and easily identified in pebble counts. The presence of glacially moulded pebbles of sedimentary origin in basal till on the Mt. Carleton massif suggests that ice passed over the highest elevations at some point. Tors at these elevations indicate they may have been exposed as nunataks during early stages of deglaciation.

A mineralised Early Carboniferous caldera complex, northern Cape Chignecto: a progress report

\author{
D.J.W. Piper \\ Atlantic Geoscience Centre, Geological Survey of Canada, Bedford Institute of Oceanography, P.O. Box 1006, \\ Dartmouth, Nova Scotia B2Y 4A2, Canada \\ and \\ H. Pancura and G. Pe-Piper \\ Department of Geology, St. Mary's University, Halifax, Nova Scotia B3H 3C3, Canada
}

On the northern side of the Cape Chignecto Peninsula, Fountain Lake volcanics have been previously mapped as thrust over the Cape Chignecto Pluton. Re-examination of the contact at Seal Cove shows that the northern part of the mapped Cape Chignecto granite is a subvolcanic rhyolite, with a complex sequence of hematitic and silicic alteration, cut by minor mafic dykes. This is structurally overlain by thick diabase with partly assimilated allochthonous rhyolite blocks, some with volcaniclastic conglomerate, indicating an original extrusive setting. Parts of this diabase show strong thrust deformation. It is overlain by a complex sequence of subvertical slabs of volcaniclastic sediment and basaltic lavas engulfed in intrusive subvolcanic rhyolite. The basaltic lavas have reddened tops and interflow sediments.

Further north, at Green Cove, is a thick sequence of extrusive agglomerate and basalt flows. We have not yet been able to gain access to the potential contact zone between subvolcanic and volcanic rocks. Further north still, at Squally Point, a sequence of interbedded thyolite and basalt flows, with minor sediment intercalations, shows large-scale rifting, stoping and injection of irregular ring dykes around diabase plugs. The entire sequence shows flat-lying brittle thrusts that have concentrated sulphide mineralisation and are cut by later mafic dykes and by vertical faults with barite mineralisation. 


\title{
Geology and environment; earth first?
}

\author{
A.G. Pronk \\ Department of Natural Resources and Energy, Geological Surveys Branch, P.O. Box 6000, \\ Fredericton, New Brunswick E3B 5H1, Canada
}

The chemistry in its early history determined the origin of life on this planet; geology and climate determined where people went from hunter/gatherer to farmer. Geology determines the availability of energy and other resources. Geology puts limits on the total system we call Earth (dolphins probably call it Ocean), limits to population and consumerism. Geology gives us many basic needs but indirectly also many problems. An orebody can be considered a natural toxic dump that probably would do the least damage if it were left buried. In a natural system all components of the ore would somehow be used by organisms, or redeposited elsewhere; we use only a small portion of it and discard the rest. It is this rest that causes all the problems resources and other industries are facing today. We have to learn to use this rest in a positive way at all cost. Large volumes of contaminated soil can be treated as ore, the usable products extracted, the soils returned in situ, and minor "waste" is "stored" for future treatment (waiting for a process or miracle; it is being done).

Geology also supplies us with data to quantify changes in our climate, sea level, atmosphere and ocean composition that can be used to anticipate future changes (natural and man-made). It teaches us how organisms react to environmental change; do they adapt, migrate, or become extinct? As earth scientists we have a different view of our planet and probably know more about it than the average scientist. It is rewarding to be involved in educating children, teachers, and nature and environmental groups. It will make everyone aware that it has to be Earth First, and given the opportunity nature will take care of itself!

The metamorphic distinction of tectonostratigraphic terranes in Nova Scotia

$$
\begin{gathered}
\text { R.P. Raeside } \\
\text { Department of Geology, Acadia University, Wolfville, Nova Scotia BOP IXO, Canada }
\end{gathered}
$$

Tectonic terranes are normally best defined by stratigraphic differences, faunal provincialism, and paleomagnetic latitudes. However, terranes may also be distinguished if they display individual, pre-amalgamation, metamorphic and deformational signatures. Asymmetric metamorphic processes may also develop across evolving plate boundaries, and would aid in the recognition of former terranes. Distinction of terranes by investigation of their tectonothermal history is most applicable to deeply eroded, older orogens.

In Nova Scotia, stratigraphic differences (both ages and lithologies)are pronounced in five terranes, although insufficient paleomagnetic data are available to display former latitudinal separation. However, the metamorphic histories of the basement and cover sequences are among the most distinctive aspects of each of the terranes. Basement rocks in the Blair River Complex parautochthonous terrane display mid-Proterozoic upper amphibolite (bathozone 5) to granulite-facies metamorphism, dated at about $1040 \mathrm{Ma}$ (U-Pb, zircon). The Aspy Suspect Terrane displays orthogneissic basement ( $433 \pm 20 \mathrm{Ma}$, U-Pb, zircon) overlain by paragneisses, metamorphosed to bathozones 4,5 and 6 , with depth of metamorphism increasing to the south. The Bras d'Or Terrane preserves bathozone 1 and 2 gneisses, overlain by sedimentary units which have locally developed bathozone 1 assemblages adjacent to dioritic plutons. The diorites yield early Cambrian U-Pb zircon ages, although the metamorphism is poorly age-constrained. ${ }^{40} \mathrm{Ar} /{ }^{9} \mathrm{Ar}$ cooling ages indicate tectonothermal activity was complete in this terrane by $440 \mathrm{Ma}$. The Mira Terrane may contain basement gneisses (early Hadrynian), but is predominantly composed of greenschist or sub-greenschist to amphibolite facies bathozone 2 and 3 assemblages, of Devonian age, and may be deposited on, or tectonically emplaced over, upper granulite facies lithologies.

Metamorphic effects related to the juxtaposition of the terranes in Nova Scotia appear to be limited, implying amalgamation by strike-slip or low-temperature processes and permitting the use of metamorphic differences in the discrimination of terranes.

\section{A compilation of eastern Canadian historic tsunamis}

\author{
A. Ruffman \\ Geomarine Associates Limited, P.O. Box 41, Station M, Halifax, Nova Scotia B3J 2L4, Canada
}

The Canadian Hydrographic Service has completed a compilation of known historic tsunamis from 1755 to the present. Previously, only the November 18, 1929 tsunami from the Laurentian Slope "Grand Banks" Earthquake was recorded in the literature; there was also a brief mention of an 1864 event in the Avalon Peninsula. The 1864 St. Shotts tsunami is now suspected to be related to a local felt event and may be related to seismic activity in the Laurentian Slope Seismic Zone.

Tsunamis are now known in Lake Ontario with a possible tsunami in Lake Erie. The Bay of Fundy area, southwest of Nova Scotia, northern Cape Breton Island and the Gulf of St. Lawrence have all experienced tsunamis. A widespread event in 1848 
affected northeast Newfoundland from St. John's to southern Labrador. The tsunami generated by the great Lisbon Earthquake of November 1, 1755 is now known to have affected northeast Newfoundland. The number of eastern Canadian tsunamis now totals at least eleven. A rock fall tsunami event is also known in Western Brook Pond in Newfoundland. Only the 1929 tsunami is known to have cost lives. The November 18, 1929 tsunami's death toll is revised to include a death in Nova Scotia. This tsunami is shown to have refracted counterclockwise around the Avalon Peninsula and to have affected northeast Newfoundland in the early hours of November 19, 1929. A major storm tide accompanied a large storm the next morning just after daybreak on November 19, 1929 and this high lunar/storm tide is often confused by people as being the effects of the tsunami.

\title{
Lithostratigraphic revision of the Upper Carboniferous to Lower Permian strata of the Cumberland and Pictou groups in the Cumberland Basin, Nova Scotia, and the regional implications for the Maritimes Basin

\author{
R.J. Ryan, R.C. Boehner and J.H. Calder \\ Nova Scotia Department of Mines and Energy, P.O. Box 1087, Halifax, Nova Scotia B3J 2X1, Canada
}

The late Paleozoic strata exposed in the Cumberland Basin part of the larger regional Maritimes Basin of Atlantic Canada have been considered as classic Carboniferous sections since their original description in the mid-1800's (Joggins Section). Stratigraphic nomenclature applied to the Upper Carboniferous strata, which locally exceed a thickness of $7 \mathrm{~km}$, is problematic due to numerous poorly defined or informal units and a confusing mixture of litho-, bio-, and chrono-stratigraphic terminology. The Cumberland Basin is a key area in the regional nomenclature because it contains the type sections of the Cumberland and Pictou groups, and well-exposed sections of strata traditionally assigned to the Riversdale Group (abandoned and constituents incorporated into the Cumberland Group) and Canso Group (abandoned and replaced by the Mabou Group, after Belt, 1964 and 1965).

The constituent formations of the Cumberland and Pictou groups include in ascending order: Cumberland Group - (1) Claremont and (2) Boss Point (both formerly assigned to the abandoned Riversdale Group), (3) Polly Brook (new), (4) Joggins (redefined), (5) Springhill Mines (new), (6) Ragged Reef (new), (7) Malagash (new); and Pictou Group - (8) Balfron (new), (9) Tatamagouche (new), and (10) Cape John (redefined). The resulting revision of the groups is based upon formal formation subdivisions and utilizes lithostratigraphic criteria such as: composition, occurrence of coal and related strata, predominant colour and grain size, vertical and lateral variation, and stratigraphic relationships. Within the context of the Cumberland Basin the revisions are modest relocations of group boundaries in the type sections: (1) Pictou Group base shifted upsection to exclude the strata of the Malagash Formation, and (2) the repatriation of the Boss Point and Claremont formations to the base of the Cumberland Group. The revised Cumberland Group conformably and unconfonnably overlies strata of the Mabou Group (Belt, $1964,1965)$ and includes all of the grey (dominated), coalbearing strata in the basin. It also includes greybeds that were previously assigned to the base of the Pictou Group in the type section. Strata previously assigned to all or portions of the Morien Group, Stellarton Group (Formation) and Petitcodiac Group could be reassigned to the Cumberland Group and would avoid the current synonomy at the group level. The revised Pictou Group comprises all of the redbed-dominated, non coal-bearing strata above the Cumberland Group and regionally could include the Pictou Group redbeds in the Gulf of St. Lawrence as well as most of the newly introduced formations of the Prince Edward Island Group. The proposed lithostratigraphic subdivisions (new and revised) and group assignment criteria will facilitate regional correlation and basin analysis within the Maritimes Basin.

The thermal evolution of the Maritimes Basin: evidence from apatite fission track analysis and organic maturation data

\author{
R.J. Ryan \\ Department of Geology, Dalhousie University, Halifax, Nova Scotia B3H 3J5, Canada \\ and \\ Nova Scotia Department of Mines and Energy, P.O. Box 1087, Halifax, Nova Scotia B3J 2X1, Canada \\ A. Grist and M. Zentilli \\ Department of Geology, Dalhousie University, Halifax, Nova Scotia B3H 3J5, Canada
}

Sandstone drillcore and/or cuttings from seven wells in the Gulf of St. Lawrence and Cabot Strait and five drillholes from onshore have been analyzed using the apatite fission track method. Uncorrected fission track ages for the late Paleozoic sandstones range from $84 \pm 8 \mathrm{Ma}$ to $220 \pm 14 \mathrm{Ma}$. Additional samples from outcrops within the Cumberland Basin yielded uncorrected fission track ages of $167 \pm 18$ to $215 \pm 30 \mathrm{Ma}$. Corrected ages of the oldest tracks range from 210-260 Ma with the older ages tending to occur in the youngest strata. Ages corrected by the mean track length method generally yield younger ages and the downhole trend for decreasing age is more obvious. Burial history reconstructions and forward modelling can be interpreted to indicate: (1) the basin underwent rapid sedimentation and burial from about 320 to $290 \mathrm{Ma}$, (2) there was a basin-side erosion event that removed 1-3 km of strata which lasted from $270-200 \mathrm{Ma}$, (3) there was a slow unroofing (erosion) event from 200-100 Ma, (4) over the last $100 \mathrm{Ma}$ the erosion rate has been very slow, (5) there is no evidence of Triassic sedimen- 
tation or thermal activity in any of the samples from the basin studied to date, (6) the geothermal gradient, as interpreted from the TTI calculations indicates that the gradient was approximately $22-27^{\circ} \mathrm{C} / \mathrm{km}$, contrasting with gradients up to $67^{\circ} \mathrm{C} / \mathrm{km}$ previously suggested; the finite age of the samples from depths of 2.5 to $3.0 \mathrm{~km}$ also suggest that the present gradient is approximately $25^{\circ} \mathrm{C} / \mathrm{km}$.

If the interpretations above are correct then the Maritimes Basin must have covered most of the Atlantic Canada region 290
Ma prior to the erosion of the $1-3 \mathrm{~km}$ of sedimentary cover. Further documentation of this sedimentary cover can be derived from additional fission track samples within the basin strata and from the surrounding highland regions. The implications of this study to petroleum and mineral resource exploration are the subject of continued research; however, preliminary results indicate that the timing of maximum temperatures in the basin can be well constrained by combining the apatite fission track method with the stratigraphic and organic maturation data.

\title{
The Nova Scotia Youth Conservation Corps programme
}

\author{
W.D. Smith \\ Nova Scotia Department of the Environment, P.O. Box 2107, Halifax, Nova Scotia B3J 3B7, Canada
}

The Nova Scotia Youth Conservation Corps (NSYCC) programme was established by the Department of the Environment during the 1989 Spring session of the legislature. The aim of the programme is to help the government take a leading role in promoting environmental awareness, conservation and clean-up of Nova Scotia. Youths aged 17-24 are employed by the Department over the summer months in paid, productive work aimed at providing environmental services to communities throughout the Province. The services offered by the NSYCC are quite diverse and may include: enhancing public access to/awareness of the environment, erosion control projects, responding to non-hazardous environmental emergencies, and surveys on environmentally-related issues. Groups, organizations and industries interested in engaging the NSYCC in the undertaking of projects and students wishing to apply for employment with the NSYCC are invited to contact a Youth Corps Project Development Officer at the nearest Department of the Environment office. Offices are located in Halifax, Middleton, Liverpool, Yarmouth, Truro, Pictou, Port Hawkesbury, and Sydney.

\section{Quaternary map of Nova Scotia}

\section{R. Stea \\ Nova Scotia Department of Mines and Energy, P.O. Box 1087, Halifax, Nova Scotia B3J 2X1, Canada}

The Quaternary map of Nova Scotia will be published this year. The map depicts the distribution and nature of surficial deposits in Nova Scotia. Also on the map is a summary of the glacial history of the region, and the locations of type stratigraphic sections with brief descriptions. The map will be available in digital form from the Land Registration and Information Service in Amherst. It was put on the Caris Gis System. The map will be an aid for mineral exploration, environmental assessment and industrial construction, as well as a useful summary of the landscape for scientists and the public.

\section{Inversion of Taconian structure during Acadian overthrusting, Port Au Port Peninsula, Newfoundland}

\author{
G.S. Stockmal \\ Geological Survey of Canada, Atlantic Geoscience Centre, P.O. Box 1006, Dartmouth, Nova Scotia B2Y 4A2, Canada \\ and \\ J.W.F. Waldron \\ Department of Geology, St. Mary's University, Halifax, Nova Scotia B3H 3C3, Canada
}

The structural front of the northern Canadian Appalachians lies submerged beneath the Gulf of St. Lawrence for most of its length. It is oriented parallel to and lies just offshore of the west coast of Newfoundland as far south as the Port au Port Peninsula, where it and associated structures come ashore and are exposed. The structure of the Port au Port Peninsula has been interpreted by us to lie within a foreland "triangle zone" that developed during Ordovician ("Taconian") and Siluro-Devonian ("Acadian") compressional episodes; importantly, some early Taconian structures affecting the Cambro-Ordovician carbonate platform were extensional. Carboniferous strike-slip deformation is minor, overprinting earlier structures. Structural interpretation has been facilitated by our recognition that restricted Middle Ordovician basins, which formed adjacent to early Taconian normal faults and within fault-bounded graben, were "inverted" by reverse-sense reactivation of the associated normal faults during subsequent orogenic shortening. These basins contain the spectacular conglomeratic Cape Cormorant Formation (upper Table Head Group) and lower Goose Tickle Group turbiditic flysch.

Local overturning of the upper detachment of the triangle zone, along the extreme western edge of the peninsula, is considered a direct consequence of basin inversion. Structural thinning of overturned stratigraphy can explain perplexing map and 
outcrop patterns of units in the hangingwall of the triangle zone upper detachment. The non-cylindrical nature of this and associated structures resulted from reactivation of faults oblique to the thrust front. Other non-cylindrical complications arise due to the presence of lateral ramps that result in map-scale structural culminations and depressions. Structures mapped within the carbonate platform support our previous interpretation that the platform is highly transported.

\title{
Structural features and tectonic implications of a sub-horizontal cleavage in metavolcanics and metaturbidites of the
} Jeffers Group, Cobequid Highlands, Nova Scotia

\author{
T.R. Stokes \\ Department of Geology, Dalhousie University, Halifax, Nova Scotia B3H 3J5, Canada \\ and \\ J.B. Murphy \\ Department of Geology, St. Francis Xavier University, Antigonish, Nova Scotia B2G 1C0, Canada
}

The late Proterozoic Jeffers Group, Avalon Composite Terrane, Nova Scotia, consists of arc-related, mafic to felsic rocks with interlayered metaturbidite sequences. The Jeffers Group was metamorphosed to greenschist facies and deformed prior to the (ca. $606 \mathrm{Ma}$ ) intrusion of the Jeffers Brook diorite. The intensity and style of deformation of the Jeffers Group, atypical of Avalonian rocks, is characterised by a sub-horizontal to moderately dipping, penetrative cleavage. Although the kinematic interpretation of this Precambrian cleavage is hindered by a Carboniferous overprint (e.g., in the Harrington River/Lynn Road area), other areas (such as at Jeffers Brook) demonstrate unequivocally that the deformation is of Proterozoic age. In this latter area the sub-horizontal cleavage: (i) cross-cuts earlier subhorizontal folding; (ii) forms wide zones (10's metres) of intense foliation commonly associated with steeply dipping kink bands, which strike sub-parallel to the cleavage; (iii) develops a shallow, south-southwestly plunging, chlorite lineation; (iv) is associated with sub-parallel calcite veining; and (v) lacks mesoscopic kinematic indicators, but displays microstructures that suggest a northwesterly direction of thrusting. In contrast, the sub-horizontal cleavage in the Harrington River/Lynn Road area is associated with: (i) sub-parallel granite/pegmatite veins (of possible Carboniferous age); (ii) kink bands formed by offset of E-W trending joints; (iii) a south-southeasterly plunging mineral lineation; (iv) metre scale folding adjacent to an E-W trending (strike-slip?) fault of Carboniferous age; and ( $v$ ) a shallow, northerly dipping zone of brittle reverse faulting. From these observations it is hypothesised that the exposed Jeffers Group displays the stratigraphic base of a northerly verging, Precambrian thrust system. This ductile deformation is characterised by a pervasive subhorizontal cleavage with a strongly developed stretching lineation and a lack of discrete thrust surfaces and thrust-related folding (the style and direction of thrusting is similar to that proposed for Precambrian deformation within the stratigraphically equivalent Folly River Formation to the east). During the Carboniferous, the Jeffers Group was probably uplifted and locally overprinted by a more brittle, thrusting event with a southerly transport direction.

\section{Siluro-Devonian tectonostratigraphic relationships, western margin of Elmtree Inlier, northern New Brunswick}

\author{
J.A. Walker, S. Gower \\ New Brunswick Department of Natural Resources and Energy, P.O. Box 50, Bathurst, New Brunswick E2A 3Z1, Canada \\ and \\ S. Leblanc \\ Department of Geology, Acadia University, Wolfville, Nova Scotia BOP 1X0, Canada
}

Silurian Chaleurs Group rocks occur in the vicinity of Jacquet River to the west of the Ordovician Elmtree Inlier. The oldest Chaleurs Group rocks are conglomerates and limestones (probably Middle Silurian) that are overlain by mafic and felsic volcanic rocks. These volcanic rocks were previously assigned to the Early Devonian Dalhousie Group. The boundary between the Chaleurs and Dalhousie groups is tentatively drawn at the top of a unit containing mafic volcanics and redbeds, which underlie the first fossiliferous Lower Devonian siltstones. This is compatible with the definition of the type Chaleurs Group in the Gaspe.

Folding and deposition probably occurred simultaneously because folds in older parts of the Chaleurs Group appear to be overstepped by younger strata. The area is also transected by several easterly to northeasterly trending faults all of which show dextral offset. The time of movement along these faults seems to become younger from north to south; faults in the north are overstepped by Upper Silurian units whereas faults in the south cut Lower Devonian strata.

Overthrusting of the Deveraux oceanic fragment, exposed within the Elmtree Inlier, in the Late Ordovician to Early Silurian was responsible for the syndepositional deformation in the Chaleurs Group rocks. Thus, Silurian volcanism occurred in a compressional regime although pyroxene compositions from samples taken in the mafic volcanic belt suggest a tensional tectonic environment. 


\title{
Proterozoic orogens of Labrador: analogues for the deeper levels of Phanerozoic orogens
}

\author{
R.J. Wardle \\ Geological Survey Branch, Newfoundland Department of Mines and Energy, P.O. Box 8700, St. John's, Newfoundland AlB 4J6
}

The eastern Canadian Shield consists of the Archean cratons of the Superior and Nain provinces, and a collage of Proterozoic orogens ranging in age from 1.8 to $1.0 \mathrm{Ga}$. Recent work has seen a dramatic reappraisal of the tectonic evolution of this area and emphasized the similarity between the Proterozoic mobile belts and the inferred deeper levels of Phanerozoic orogens.

The oblique collision of the Superior and Nain cratons between 2.1 and $1.8 \mathrm{Ga}$ is recorded in the eastern Churchill province (New Quebec and Torngat orogens) where deformation was of transpressional nature and involved large-scale reworking of Archean crust and relatively little preservation of juvenile crust. In the same period the Shield also grew to the south through accretion in the Makkovik Province. Post-1.8 Ga growth was dominated by accretion of large amounts of juvenile crust from the south in a variety of events between 1.7 and $1.2 \mathrm{Ga}$, and terminated in continent-continent collision during the ca. 1.0 Grenville Orogeny. Much of the previously accreted crust was redeformed during this terminal event such that it now lies largely within the Grenville Province.

The eastern Churchill Province represents a relatively shortlived $(0.3 \mathrm{Ga})$ orogenic belt that resembles the seismically inferred deep-crustal configuration of the northern Appalachian Orogen. The Grenville Province (including the earlier accretionary crust), however, represents a much longer period (at least 0.8 $\mathrm{Ga}$ ) of progressive accretion and continental outgrowth that bears more resemblance to the Tibet - Himalayas orogenic complex.

New base metal discovery in the Siluro-Devonian Tobique Belt, New Brunswick

\author{
R.A. Wilson \\ Geological Surveys Branch, Department of Natural Resources and Energy, P.O. Box6000, \\ Fredericton, New Brunswick E3B 5H1, Canada
}

Nova Gold Resources' Sewell Brook base metal discovery, $130 \mathrm{~km}$ southwest of Bathurst near Plaster Rock, represents the first volcanogenic massive sulphide deposit to be found in the Siluro-Devonian Tobique Group of northwestern New Brunswick. Like the Ordovician Tetagouche Group, which hosts numerous base metal sulphide deposits in the Bathurst district to the northeast, the Tobique Group consists of a thick succession of sedimentary rocks and bimodal volcanic rocks. However, the Sewell Brook deposit is hosted by felsic volcanic rocks and in several respects appears to conform to a Kuroko-type model, whereas most Bathurst camp deposits are hosted by fine-grained sedimentary rocks.

Volcanic rocks of the Tobique Group include massive to pillowed basalts and a series of subaqueous rhyolitic flows and domes. Rhyolites are predominantly glassy lavas, characterized by spherulitic and perlitic textures, and widespread development of pseudo-fragmental textures produced by patchy or nodular devitrification and chloritic alteration. Locally, a combination of rapid aqueous chilling and mechanical disintegration at the margins of actively moving flows has produced a thick mantle of hyaloclastic breccia and microbreccia enveloping units of massive glassy rhyolite.

At Sewell Brook, successive rhyolite/hyaloclastite sequences are separated by beds of marine siltstone and sandstone. Hyaloclastic breccias host the sulphide lenses, which can reach grades as high as $41 \% \mathrm{~Pb}-\mathrm{Zn}$ over $19 \mathrm{ft}$. The sulphide bodies are replacement deposits, situated within the upper portion of porous hyaloclastic units, immediately beneath the (paleo) sea floor. The degree of replacement is variable: in places only the breccia matrix is replaced, whereas in the highest grade zones the entire rock is replaced by sphalerite and galena, leaving relict "ghost" shapes of fragments. A locally high-grade copper zone (e.g., 17\% over $5 \mathrm{ft}$.) lies stratigraphically below the $\mathrm{Pb}-\mathrm{Zn}$ zone in some drill holes; the source of this copper is unclear as mafic rocks are not present in the vicinity of the deposit.

The Sewell Brook deposits more closely resemble Kurokotype than Bathurst-type deposits as pyrrhotite, magnetite, and Algoma-type iron formation are absent at Sewell Brook, cherty silicification is common, and the ore is hosted by brecciated felsic lavas rather than by sedimentary rocks. However, Sewell Brook differs from Kuroko deposits in that it is a replacement deposit and not a result of sea-floor exhalative activity. Furthermore, significant quantities of sulphates, especially barite, do not seem to be present. It is suggested that hydrothermal convection cells became active during periods of quiescence following extrusive activity. Hydrothermal fluids circulated freely through the rhyolites (rendered permeable by devitrification) and through porous hyaloclastic rocks, leaching $\mathrm{Pb}$ and $\mathrm{Zn}$ and producing chloritization and local silicification. Deposition of sulphides was controlled by the porosity of the hyaloclastic breccias, and by temperature (i.e., proximity to the seafloor). 


\title{
Constructional features and their relationship to sulphide deposits in the upper part of the Troodos Ophiolite, Cyprus
}

\author{
J.S. Yang and J.M. Hall \\ Department of Geology, Dalhousie University, Halifax, Nova Scotia B3H 3J5, Canada
}

Field observations and measurements were carried out along 18 profiles, spaced at about $2.5 \mathrm{~km}$ and oriented approximately normal to the average spreading direction, in the extrusive sequence of the Troodos Ophiolite, Cyprus. Within the $45 \mathrm{~km}$ of spreading distance covered by the 18 lines, the proportion of pillowed lava flows at different stratigraphic levels is remarkably constant and a high proportion of pillows and thick pillowed sequences are generally concentrated at the top of the extrusive sequence. At least two volcanic cycles are present in vertical sections of the central part of the area. Dykes occur throughout the extrusive sequence but increase in abundance with depth at different rates from place to place. Three regional hydrothermal alteration zones can be recognized within the extrusive sequence.
They are, from top to bottom, the brownstone (approximately to the zeolite facies), transition, and greenstone (approximately to the greenschist facies) alteration zones. Regional development and zonation of hydrothermal alteration show simple correlation with dyke growth with depth. The 11 sulphide deposits in the study area, comparable with that observed on the present oceanic spreading ridges, occur in four groups in the extrusive sequence and generally occur just above the $25 \%$ dyke density contour on the flanks of major areas of sheet flows. It is likely that differential preservation has played a role in the present distribution of sulphide deposits, and dykes were possibly a major heat source responsible for the hydrothermal alteration and sulphide mineralization accompanying crustal formation in the ancient ocean.

\section{Paleozoic ironstones of the Canadian Appalachians}

\section{G. Yeo \\ Department of Geology, Acadia University, Wolfville, Nova Scotia B0P IX0, Canada}

The occurrence of an extraordinary number of ironstone deposits, ranging in age from Middle Cambrian to Early Devonian, in the northern Appalachians, requires some explanation. Although none are currently economic, most have been mined in the past. They fall into two classes according to age and paleolatitude:

(1) High latitude, Middle Cambrian to Early Ordovician ironstones:

McLean Brook Fm. (MC) Cape Breton, N.S.

Ferrona Fm. (LC-EO) Antigonish Highlands, N.S.

Wabana Gp. (LC-EO) Conception Bay, Nfld.

(2) Low latitude, Silurian to Early Devonian ironstones:

McAdam Fm. (ES) Antigonish Highlands, N.S.

Smyrna Mills Fm. (ES) Woodstock area, N.B.

Torbrook Fm. (ED) Annapolis Valley, N.S.

These episodes of iron deposition were punctuated by orogeny in the Early Cambrian, Middle Ordovician, and Middle Devonian. With one exception, Smyrna Mills, these deposits are oolitic, and were deposited in upward-shoaling, shallow marine settings on the Avalon block (including the Meguma Terrane) prior to its docking with North America. The manganiferous, Smyrna Mills ironstones were deposited in a relatively deep water, restricted basin on the Central/Gander block after it had docked.

Although a range of mechanisms may result in deposition of ironstone, most of these involve low clastic influx, continuous supply of iron, and sediment reworking. These were all factors during deposition of the northern Appalachian ironstones. Clastic sedimentation rates would have been reduced during periods of tectonic quiescence. Scarcity of carbonates or evaporites in the ironstone-bearing sequences suggests humid climates, which should favour chemical weathering and supply of dissolved iron to basins. Penecontemporaneous volcanism was a potential iron source during Ferrona, Smyma Mills, and Torbrook times. Deposition during times of global sea-level rise (2nd order eustatic cycles) would favour reworking of older weathered sediments, while upward shoaling (3rd/4th order cycles) in the iron-rich successions would favour still-stand conditions and chemical sedimentation.

Sedimentation in the inner Cornwallis Estuary, Minas Basin, Nova Scotia: implications for contaminant accumulation

\author{
G. Yeo, E. Bishop, A. Dickinson \\ Department of Geology, Acadia University, Wolfuille, Nova Scotia BOP 1XO, Canada \\ and \\ R. Faas \\ Department of Geology, Lafayette College, Easton, Pennsylvania 18042, U.S.A.
}

The estuary of the Cornwallis River is a macrotidal system within the Minas Basin, like the better-known Cobequid Bay -
Salmon River estuary. Compared to the latter, it is mud-dominated. Tidal range and flow conditions are highly variable: 


$\begin{array}{lccc}\text { Site: } & \begin{array}{c}\text { Port } \\ \text { Williams }\end{array} & \begin{array}{c}\text { New } \\ \text { Minas }\end{array} & \text { Kentville } \\ \text { Spring tide range }(\mathrm{m}): & 12.15 & 4.1 & 2.15 \\ \text { Max. velocity }(\mathrm{cm} / \mathrm{s}): & 177 & 132 & 83 \\ \text { Min. velocity }(\mathrm{cm} / \mathrm{s}): & 58 & 29 & 21\end{array}$

Except at slack water, when suspended sediment settles out rapidly the water column is well-mixed. Suspended sediment concentration varies from $50 \mathrm{mg} / 1$ near Wolfville to $>4.5 \mathrm{~g} / 1$ at the turbidity maximum between New Minas and Kentville. Hydraulic sediment sorting is very efficient in this system, with deposits becoming much finer grained up-river. With decreasing velocity, grain size, depth, and bedforms also vary systematically upstream and throughout the neap-spring tide cycle. At New Minas and above, water-saturated clays predominate and bars are smooth, with localized rip-up grooves. On bars at Port Williams and below, silt and fine sand form continuous crested and small linguoid ripples, while fine to coarse sands and gravelly sands form large 3-D ripples. Between Port Williams and New Minas, plane or rippled, silty beds are interbedded with water-saturated clays deposited at slack water. Overpressure conditions resulting from the ebb of overlying waters produce numerous fluidization features.

Except where the river has cut into Triassic sandstone, the banks are dyked and locally faced with rip-rap. Along most of their length they are mud, deposited from suspension, and intensively gullied. Bank mud deposits are continuously recycled to the river by fluidized flow, scouring, or undercutting and slumping. Seeps and springs are common along the banks at low water.

The Cornwallis estuary has been closed to fishing and recreational use for several years because of persistent pollution. Dissolved contaminants may be carried into the system through tidal pumping of groundwater, as well as surface runoff. It is likely that such contaminants are preferentially absorbed onto clays or organic particles (hydraulically equivalent to finegrained inorganics). Since these are not flushed out of the estuary, but concentrated upstream, it is likely that contaminant levels are building up in the system.

Tidal facies and stratigraphy of a muddy macrotidal estuary in the southern bight of the Minas Basin, and potential for synthetic aperture radar (SAR) monitoring of active intertidal areas

\author{
G. Yeo, N. McDow \\ Department of Geology, Acadia University, Wolfuille, Nova Scotia BOP 1XO, Canada \\ and \\ B. Tetley \\ Nova Scotia College of Geographic Sciences, Lawrencetown, Nova Scotia BOS 1M0, Canada
}

Three major macrotidal estuaries empty into the Minas Basin, the Comwallis, Avon, and Cobequid Bay - Salmon River estuaries. The sedimentology of the Cornwallis estuary is the least studied of these. The Comwallis estuary can be subdivided into three areas, the inner estuary, between Wolfville and Kentville (described elsewhere), and the outer estuary, separated into eastern and western parts by the Cornwallis River channel itself.

Six main facies zones may be recognized in the outer beach, nearshore mudflats, offshore mudflats, sandflats, and sand bars. High (Spartina patens) and low salt marsh (S. alterniflora) are readily distinguished by vegetation assemblages. Relatively narrow sand beaches are developed locally, especially at the base of actively eroding sandstone cliffs. Nearshore mudflats are planar and water saturated. Offshore mudflats are more silty, typically planar or rippled, and dissected by tidal channels. Sandflats are typically rippled and coarsen offshore. Sand bars, developed within and at the margins of major channels, are characterized by 2-D and 3-D megaripples, commonly with smaller, superimposed ripples. These facies are comparable to those described in the Cobequid Bay - Salmon River estuary, although the proportion of sandy facies is much higher there.

The westem and eastern parts of the outer estuary are distinguished by much thinner sediment cover and corresponding abundant bedrock outcrop in the latter. The western part has no outcrop south of Kingsport. The core of the Starr's Point bar is not exposed, but the abundance of glacial clasts in the outer mudflat area suggests it has a till core.

Over most of the eastern area, a thin veneer of tidal sediments rests on a wave-cut platform of Triassic sandstone. "The Guzzle", which separates Boot Island from Evangeline Beach, is a historically recent (ca. 1800) channel, but it follows the course of an older bedrock valley. The Quaternary stratigraphy preserved in The Guzzle comprises: red till, probably derived from the north; laminated red and grey mud, interpreted as delta bottomset deposits; a peat layer with tree stumps dated at about 4000 B.P.; grey marine, tidal creek, and saltmarsh muds; drowned gravel beach ridges; and recent tidal muds and sands.

The major facies zones and bedrock features show up well on Synthetic Aperture Radar (SAR) images. Comparison of old maps and air photos shows that the outer facies zones are relatively mobile, in contrast with the salt marshes, where channels may persist for centuries. It is not clear whether these intertidal facies shifts are due to storms or gradual processes. SAR will be a useful tool for studying such changes. 
Hydrothermal ore genesis: the role of carbon

\author{
M. Zentilli \\ Department of Geology, Dalhousie University, Halifax, Nova Scotia B3H 3J5, Canada \\ and \\ M.C. Graves \\ Cuesta Research Limited, Dartmouth, Nova Scotia B3A IV8, Canada
}

Organic matter and its derivatives have long been recognized as essential participants in the formation of a variety of sedimentary and diagenetic ore deposits and as empirical components in higher temperature ore environments. Advances in the understanding of hydrocarbon migration and ore fluids allows an evaluation of interactions between them. The sequential consideration of source, mobilization, migration, trapping, and preservation provides a powerful framework for analysis of the interactions.

Source: Exhalations of methane or metal-bearing hydrothermal fluids both can provide nutrients that can lead to high productivity of not only metal and sulphur-fixing bacteria but bulk carbon in the form of increased biomass. Sedimentary and diagenetic concentrations of metals in reducing environments are preserved in rocks which are often also potential source rocks for hydrocarbons. As such these rocks are long term repositories of metals, sulphur, and carbon compounds. The oxidation of carbon in the diagenetic environment can result in the fixing of carbonate in rocks that otherwise would not become as potently reactive to any later fluids. Carbonate cementation imposes important constraints on the permeability history of any rock.

Mobilization: Maturation of hydrocarbons can be an agent in generating high fluid potentials aiding mechanically fluid expulsion and affecting the physical properties of the rocks. Further prograde metamorphic reactions continue to produce fluids which in the presence of carbon are restricted in their chemical properties. Overpressures thus generated often lead to hydraulic (brittle) fracturing in otherwise ductile rocks.
Migration: Migration of hydrocarbons is a process that moves reduced carbon and sulphur from a restricted source rock to reduced reservoir rocks, which may have had little reduced carbon before the process took place. The transport pathways can be hundreds of kilometres in lateral extent and can be used later by basinal fluids with metal carrying capacity. The transported carbon and sulphur are also available at these new sites for metalcarrying fluids of significantly different sources and later ages.

Trapping: Mechanically, hydrocarbons have the ability to keep pores open by preventing cementation. Chemically, both autochthonous and transported hydrocarbons can act as reductants and conveniently they reside in a porous reservoir. The trapped hydrocarbons prepare the reservoir for physical and/or chemical entrapment of metal-carrying fluid. Little evidence of this hydrocarbon may remain.

Preservation: The same reducing conditions necessary to preserve hydrocarbons from oxidation and destruction are required to preserve sulphides, hence the common association of bitumen or graphite with sulphides.

This framework is also useful in considering magmatogenic ore models. The presence of reduced (source-rock, migrating or trapped) carbon at the magma source, along the magma conduit or at the site of its final crystallization may dramatically alter magma chemistry (e.g., magnetite to ilmenite series) and oreforming capacity. The interaction of magmas with carbon may have been an important factor in the genesis of many economic tin, tungsten, uranium, copper, gold, and even some nickel and PGE deposits. 